
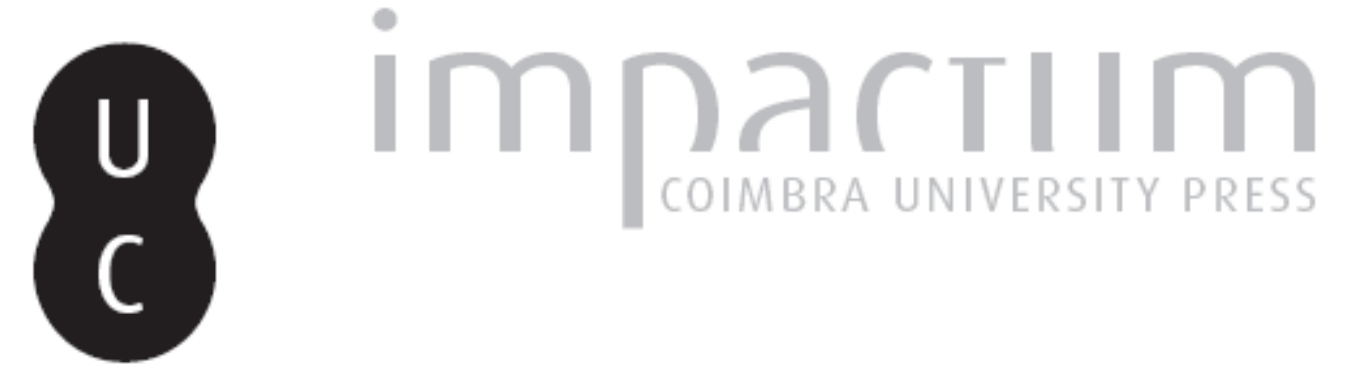

\title{
Arqueologia urbana em Viseu: primeiros resultados
}

Autor(es): $\quad$ Carvalho, Pedro Sobral de; Valinho, Alexandre Tiago Santos

Publicado por: Imprensa da Universidade de Coimbra

URL persistente:

URI:http://hdl.handle.net/10316.2/45358

DOI:

DOI:https://dx.doi.org/10.14195/1647-8657_40_2

Accessed : $\quad$ 26-Apr-2023 11:49:42

A navegação consulta e descarregamento dos títulos inseridos nas Bibliotecas Digitais UC Digitalis, UC Pombalina e UC Impactum, pressupõem a aceitação plena e sem reservas dos Termos e Condições de Uso destas Bibliotecas Digitais, disponíveis em https://digitalis.uc.pt/pt-pt/termos.

Conforme exposto nos referidos Termos e Condições de Uso, o descarregamento de títulos de acesso restrito requer uma licença válida de autorização devendo o utilizador aceder ao(s) documento(s) a partir de um endereço de IP da instituição detentora da supramencionada licença.

Ao utilizador é apenas permitido o descarregamento para uso pessoal, pelo que o emprego do(s) título(s) descarregado(s) para outro fim, designadamente comercial, carece de autorização do respetivo autor ou editor da obra.

Na medida em que todas as obras da UC Digitalis se encontram protegidas pelo Código do Direito de Autor e Direitos Conexos e demais legislação aplicável, toda a cópia, parcial ou total, deste documento, nos casos em que é legalmente admitida, deverá conter ou fazer-se acompanhar por este aviso.

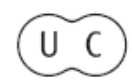


UNIVERSIDADE DE COIMBRA

FACULDADE DE LETRAS

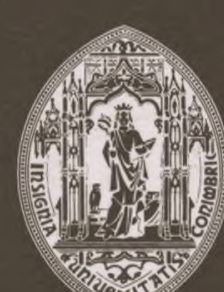

CONIMBRIGA

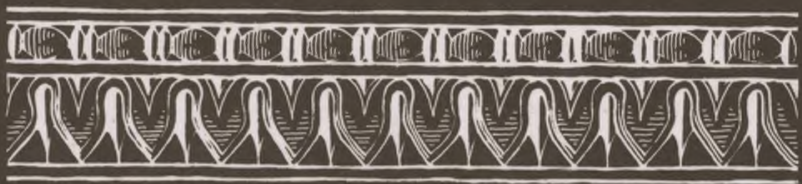

VOLUME XL - 2001 
PEDRo SobRal DE CARVALHO

Mestre em Arqueologia. Universidade do Porto.

AleXandre Tiago Santos Valinho

Licenciado em História (var. de Arqueologia). Universidade de Coimbra.

\section{ARQUEOLOGIA URBANA EM VISEU. PRIMEIROS RESULTADOS}

“Conimbriga" XL (2001) p. 37-64

RESUMO: Apresentam-se os resultados de duas intervenções arqueológicas de emergência realizadas no Centro Histórico da cidade de Viseu.

Do conjunto de achados, merece especial destaque a identificação de restos de dois pisos de barro vermelho/alaranjado com cerâmicas cronologicamente inseríveis no séc. III a.C. Um destes pisos foi descoberto no interior de uma casa na Praça D. Duarte e o outro na Rua do Gonçalinho.

Do conjunto de materiais exumados interessa sublinhar um fragmento cerâmico decorado com fiada de suásticas, um vaso com decoração impressa e incisa e dois cossoiros.

Foram igualmente recolhidos importantes dados sobre a ocupação romana e medieval.

A identificação de uma via lajeada confirma a Rua do Goçalinho como um eixo viário na época romana que poderá corresponder ao decumanus maximus.

ABSTRACT: The present paper presents the results concerning two archaeological interventions in Viseu's historical center.

From the bulk of the materials recovered we would like to point out the remains of two red/orange clay pavements related to ceramic dating from the III century B.C. One of these was recovered from the interior of a house in Praça D. Duarte, the other from Rua do Gonçalinho.

Conimbriga, 40 (2001) 37-64 
From the rest of the materials some are note worthy, such as: one ceramic fragment decorated with "swastika" motifs; one pot with impressed and incised decoration; and two spindle-whorls.

Relevant information, regarding the medieval and Roman periods, was also recovered. The identification of a pavement of flagstones confirms Rua do Gonçalinho as one of Viseu's main axis during the Roman period, which could correspond to the decumanus maximus. 


\section{ARQUEOLOGIA URBANA EM VISEU. PRIMEIROS RESULTADOS}

\section{Introdução}

A empresa ArqueoHoje, Conservação e Restauro do Património Monumental, Lda (Viseu), tem desenvolvido, desde 1997, intervenções arqueológicas pontuais no Centro Histórico da cidade de Viseu. Estes trabalhos fazem parte das prerrogativas exigidas pela autarquia viséense para o licenciamento de obras nesta zona da cidade. Pena é que outras áreas onde existe o risco sério de surgirem vestígios arqueológicos não sejam abrangidas por esta exigência. Referimo-nos em concreto à zona do Cerrado, ao Largo Mouzinho de Albuquerque, à Av. Emídio Navarro e à Praça da República. Trata-se de alguns locais onde existem referências bibliográficas suficientes para as caracterizar como “áreas arqueológicas”[vide entre outros Alarcão, 1989; Coelho, 1941, 1943, 1950; Girão, 1925; Ribeiro, 1971; Vale, 1971; Vaz, 1997].

Este trabalho reporta-se apenas aos resultados das intervenções realizadas num edifício situado na Praça D. Duarte, $n .^{\circ} 1$ e $3^{1}$ e nas Ruas do Gonçalinho, Prebenda e Escura² .

Os técnicos que realizaram o trabalho de campo foram Pedro M. Sobral de Carvalho (responsável técnico/científico), Filipe João

1 Obras de reconstrução do edifício. A intervenção arqueológica foi financeiramente suportada pelo proprietário e decorreu entre os dias 5 e 7 de Abril de 1999 (trabalhos aprovados pelo IP A através do Proc. ${ }^{\circ}$ 99/01 (226), of ${ }^{\circ} 1015$, datado de 11 de Março de 1999).

2 Realizados no âmbito da abertura de valas para infra-estruturas subterrâneas e repavimentação. Os trabalhos arqueológicos foram financeiramente suportados pela Câmara Municipal de Viseu e decorreram entre 08 de Março e 10 de Maio do ano de 1999 (aprovados pelo IPA através do Proc $^{\circ}$ 99/1 (291), of ${ }^{0} 1199$, datado de 23 de Março de 1999).

Conimbriga, 40 (2001) 37-64 
Carvalho dos Santos, Alexandre Jorge Cordeiro Canha e Artur Miguel Alpande Serra ${ }^{3}$. A Dr* Clara Portas Matias foi a responsável científica pelo acompanhamento arqueológico de parte das Ruas do Gonçalinho e Prebenda.

Os desenhos dos materiais arqueológicos - financeiramente suportados pela ArqueoHoje, Lda — são da autoria de Lilia Basilio.

\section{A Praça D. Duarte, n.os 1 e 3}

O local de implantação do edifício, no ponto mais alto do relevo onde se situa a zona antiga da cidade de Viseu, junto à Sé de Viseu, fazia supor, desde o início, a existência de vestígios arqueológicos (Est. I).

A identificação de estruturas arqueológicas a cerca de $40 \quad \mathrm{~m} \quad \mathrm{a}$ Norte [VAZ, 1996 e 1997], bem como os silhares romanos existentes na base da parede Este da Sé de Viseu, tornam esta zona crucial para a compreensão da génese e história da cidade de Viseu.

À data do início dos trabalhos arqueológicos, o edifício ostentava uma planta em L, apresentando-se as paredes do lado Norte desalinhadas, ocupando uma área de cerca de $80 \mathrm{~m}^{2}$ (foto 1).

Pela observação da fachada e pelo que nos foi dito por pessoas que nos visitaram no local, o espaço que agora se estuda estaria primitivamente dividido em dois edifícios autónomos por uma parede

- Muro 4. Já neste século terá sido aberta uma porta interior em B2\ bem como terá sido fechada a porta que ligava com o exterior em C2, unificando todo este espaço.

As paredes apresentavam aparelhos diferentes, revelando diversas fases de remodelações, encontrando-se parcialmente revestidas a estuque e azulejo.

Num dos alçados interiores, mais concretamente na parede Norte

- Quadrado B4 -, encontravam-se incorporados dois fragmentos de lápides graníticas com caracteres gravados. Um destes fragmentos, localizado a cerca de $5 \mathrm{~m}$ de altura, fazia parte de uma fiada vertical de silhares que formavam esquina onde encostavam manilhas de esgoto. Cremos que primitivamente terá aqui existido uma parede que limitava

3 Quadros técnicos da ArqueoHoje, com sede social no Parque Industrial de Coimbrões, Edifício Expobeiras, Área BIC, 3500-618 VISEU.

Conimbriga, 40 (2001) 37-64 
a casa a Oeste cujo alicerce seria o Muro 1. Infelizmente, este fragmento de lápide foi desbastado, perdendo-se para sempre as restantes letras do conjunto.

O segundo fragmento, localizado na mesma direcção, mas cerca de $3 \mathrm{~m}$ mais acima, é parte de uma bela lápide previamente reutilizada em outro edifício.

\subsection{Descrição dos trabalhos}

\section{Metodologia aplicada}

Numa primeira fase e após a limpeza do terreno - remoção de lixos e do lajedo composto por grandes blocos graníticos -, quadriculou-se toda a área interior do edifício através de uma rede de quadrados de $2 \mathrm{~m}$ x $2 \mathrm{~m}$. Assim, no eixo das abcissas (x) foram atribuídas letras de A' a D e no eixo das ordenadas (y) números de 2' a 7 (Est.II).

O ponto de cota zero convencional reporta-se ao topo da soleira da entrada do edifício. As leituras, ao centímetro, daí resultantes foram todas negativas.

Numa primeira fase foram marcadas duas valas de sondagem de modo a perceber a importância do sítio: sondagem A (10 $\mathrm{m} \times \mathbf{1 , 5} \mathrm{m})$ e sondagem $B(4,5 \mathrm{~m} \times \mathbf{1 , 5} \mathrm{m})$ (vide planta da área intervencionada). De acordo com o desenrolar da intervenção, tornou-se necessário abrir novas áreas: sondagens $\mathbf{C}, \mathbf{D}$ e $\mathbf{E}$.

As sondagens $\mathbf{F}$ e $\mathbf{G}$ correspondem a áreas que foram abertas após os trabalhos de escavação. Uma vez que também nessas áreas surgiram estruturas arqueológicas, houve necessidade de acompanhar e de registar os achados. As condições destes trabalhos nem sempre foram as mais propícias, uma vez que o empreiteiro exercia uma forte pressão para que se acabassem os trabalhos arqueológicos.

\subsection{A escavação}

Para que se iniciassem os trabalhos arqueológicos foi necessário, como já foi referido, remover um lajeado composto por robustas lajes de granito que forravam o chão da área compreendida entre A'2' e A'7 e metade de B2' e metade de B7. A restante área possuía um piso em 
mosaico que foi igualmente necessário remover. Foi precisamente, segundo o relato do empreiteiro e ao limparem esta última área, sensivelmente em $\mathrm{C} 1$, que surgiu um elemento girante de urna mó manuária romana ${ }^{4}$. Outros dois fragmentos surgiram com o decorrer da remoção do lajeado. Juntamente com estas peças surgiu uma placa circular, provável base de um recipiente de grande dimensões, que, com algumas reservas, datámos da época romana. Estes materiais encontravam-se associados a um conjunto de fragmentos cerâmicos e de vidros que recolhemos (vide capítulo sobre a cultura material).

\subsection{Estruturas}

Muro 1 (Ests. Ill e IV; foto 2) - Localizado quase no extremo Este do edifício, apresentava um aparelho bem feito. Foi usada uma argamassa amarela com fragmentos de telhas de meia cana para unir as pedras.

Em A5/B5 assentava numa camada de terra negra com muitos elementos carbonosos e muitos fragmentos de telha de meia-cana associada. Pensamos que estas terras tenham sido depositadas para nivelar o solo de base de apoio deste muro, pois no extremo Sul este assenta na rocha de base.

Este muro encostava tanto na parede existente a Norte como na do Sul o que nos faz colocar a hipótese de se tratar do alicerce de uma parede exposta a Este, edificada num momento recente (séc. XX), aquando de uma ampliação do edifício em estudo.

A largura deste muro variava entre os $0,96 \mathrm{~m}$ e os $0,94 \mathrm{~m}$, enquanto que a altura média era de $1,00 \mathrm{~m}$.

O espólio associado é da época contemporânea e compõe-se sobretudo de telhas de meia cana que preeenchiam quase totalmente o espaço a Este do muro.

Muro 2 (Ests. Ill e IV; foto 2) - Este muro era bastante similar ao muro 1 na sua composição e espólio associado.

Ao invés do muro 7, este encaixava-se na parede Sul indiciando o seu prolongamento nesse sentido, enquanto que a Norte parecia apenas encostar na parede aí existente.

4 Esta peça desapareceu do local já no final dos trabalhos, alvo de um provável roubo.

Conimbriga, 40 (2001) 37-64 
A largura variava entre os $1,18 \mathrm{~m}$ e os $1,08 \mathrm{~m}$, enquanto que a altura média era de $1,00 \mathrm{~m}$.

Também neste caso, em A5/B5, o muro 2 assentava numa camada de terra negra com muitos fragmentos de telha e carvões associados.

$\mathrm{O}$ espolio recolhido entre as pedras e junto a este muro colocam-no cronologicamente num período moderno, provavelmente nos inicios do séc. XX.

Grande parte das terras onde assentavam os muros 1 e 2 apresentavam uma imensa quantidade de elementos carbonosos que nos fazem colocar a hipótese de ter havido um incêndio nesta área do edifício, numa época relativamente recente, talvez já mesmo neste século. Talvez por este motivo tenha havido necessidade de se ampliar a casa para Este, construindo-se uma nova parede - o muro 1.

Muro 3 (Est. IV; foto 3) - Este muro apresentava um aparelho pouco cuidado, com terra e pequenos fragmentos de tégulas e de imbrices no seu miolo.

Apresentava uma largura média de $0,70 \mathrm{~m}$ e $0,75 \mathrm{~m}$ de altura conservada.

A Sul este muro encostava ao afloramento rochoso.

O cabouco deste muro foi aberto num nível de terras castanhas claras que cobria o saibro rochoso.

Encontrava-se associado a cerâmicas da época romana não só de construção - tegulae e imbrices - como cerâmicas comuns e finas, com especial destaque para um fragmento de uma taça em terra sigillata hispânica, decorada, cronologicamente integrável no Alto Império (finais do I/inícios do séc. II) — e de um fragmento de unguentário em vidro verde-gelo.

Pelo que foi dito, cremos estar em presença dos alicerces de um muro da época romana, talvez dos inícios do séc. II, que faria parte de uma construção relativamente modesta.

Muro 4 (Est. V) - Muro bastante danificado a Sul onde apresenta derrube. Relaciona-se, certamente, com os alicerces de uma parede que dividia a casa, destruída antes da intervenção arqueológica. Este muro assenta no afloramento rochoso.

Muro 5 (Est. V; foto 7) — Este muro apresentava-se muito destruído, restando apenas os seus alicerces. Com $0,50 \mathrm{~m}$ de largura máxima e $0,30 \mathrm{~m}$ de altura média, deste muro só já restava uma fiada de pedras.

Encostado a este surgiu um piso de barro argamassado, pouco compacto, de coloração avermelhada que se estendia para Este e Sul,

Conimbriga, 40 (2001) 37-64 
pelas quadrículas $\mathrm{B} 2 / \mathrm{B} 3, \mathrm{C} 2 / \mathrm{C} 3$ e parte de $\mathrm{D} 2 / \mathrm{D} 3$. Urna fossa detrítica de configuração subcircular de cronologia recente (talvez já do séc. $\mathrm{XX)}$ identificada em B1/B2 atravessou este piso destruíndo-o 5 .

Junto ao extremo Sul do muro foi identificada uma fossa de configuração circular com $0,68 \mathrm{~m}$ de diâmetro e $0,42 \mathrm{~m}$ de profundidade máxima. Esta fossa encontrava-se forrada com o mesmo barro argamassado que constituía o piso. No interior da fossa foi recolhida uma enorme talha que conteria provavelmente líquidos — vinho, água, azeite - ou cereais. Esta talha, embora completa, foi infelizmente partida pelo empreiteiro que, no entanto, forneceu a informação que a boca da talha se encontrava tapada com uma pedra rectangular, em granito.

$\mathrm{O}$ espólio associado ao muro indicia uma cronologia medieval, talvez da transição da Idade Média para a Moderna (séc. XV/XVI), mas só o estudo mais aprofundado e atempado das cerâmicas poderá fornecer mais informações.

Piso de cabana pré-romano (Est. VI; fotos 4 e 5) - Em BI e B2 surgiu, a cerca de $2,20 \mathrm{~m}$ de profundidade (em relação ao ponto 0), um interessante piso de argila cuja coloração variava do laranja (textura 1) ao amarelo torrado (textura 2), muito consistente e compacto. Efectivamente, este piso apresentava-se bem conservado em B1, com coloração laranja, tendo a delimitá-lo a Este duas pequenas pedras em granito. Em B2, o piso apresentava-se remexido, estando o topo partido em fragmentos que formavam placas de barro argamassado onde estavam encrostados muitos elementos carbonosos.

O piso, muito compacto, era formado por uma argamassa de barro ao qual foram misturados fragmentos cerâmicos de fabrico manual ${ }^{6}$, o que faz pressupor que terá havido uma reestruturação do espaço ainda numa época anterior ao séc. Ill a. C.

Uma fossa aberta em B1/B2 destruiu totalmente, como já foi referido, parte do piso de barro. De facto, esta fossa aberta provavelmente num período muito recente (séc. XX), apresentava-se repleta de telhas de meia cana, vidros de garrafa, fragmentos de cerâmica vidrada, cerâmica negra de cozinha, o que indicia o seu uso como fossa detrítica.

5 Esta mesma fossa detrítica destruiu igualmente o piso de uma cabana protohistórica.

${ }^{6}$ Foi recolhido um conjunto de fragmentos deste piso armazenados conjuntamente com os inventariados.

Conimbriga, 40 (2001) 37-64 
Não foi possível definir o prolongamento do piso para A1/A2, uma vez que terá sido igualmente feita nesta área uma outra violação que rompeu e destruiu o referido piso.

Deste modo, apenas podemos referir que o piso de cabana possuía um comprimento máximo de $2,70 \mathrm{~m}$ e cerca de $1,5 \mathrm{~m}$ de largura. Este último dado é inferido partindo do princípio de que uma vez que no corte 1 não existe nenhum registo do piso, o seu limite Sul deve ter-se situado algures na sondagem A.

O espólio exumado sobre e entre o piso de barro era constituído essencialmente por fragmentos cerâmicos, manuais e feitos ao torno, lisos, grande parte destes brunidos. Sob o piso, com especial incidência em B2, foram recolhidos igualmente fragmentos cerâmicos do mesmo tipo. Foram feitas recolhas do piso e de elementos carbonosos para análises radiocarbónicas.

Estrutura em poço (Est. VII; foto 6) - À semelhança do muro 5, também numa fase do início das obras de terraplanagem e remoção de terras, após o fim dos trabalhos de escavação arqueológica; surgiu entre AI' e A2' uma estrutura definida por um "poço" aberto no saibro.

Localizado muito perto da entrada do edifício, apresentava perfuração vertical, boca de secção circular com $1,70 \mathrm{~m}$ de diâmetro e uma profundidade máxima de $2,51 \mathrm{~m}$. Ao $1,20 \mathrm{~m}$ de profundidade, este poço alargava para Sul cerca de $1 \mathrm{~m}$.

As terras - castanhas escuras, pouco compactas - que enchiam este poço continham alguns fragmentos cerâmicos que se podem dividir em dois grandes grupos: um constituído por recipientes de grandes dimensões, provavelmente romanos - dolia (Est. XIV) - e outro por fragmentos de vários recipientes proto-históricos com especial destaque para o vaso decorado com impressões circulares e fiadas de incisões oblíquas na passagem da pança para o colo (Est. X).

O grupo dos grandes vasos de armazenagem surgiu até cerca de $0,70 \mathrm{~m}$ de profundidade selando o interior do poço.

O segundo grupo ceramológico compreende cerâmicas de fabrico maioritariamente manual, com superfícies alisadas ou polidas/brunidas e raramente decoradas, cronologicamente integráveis num período compreendido entre o séc. IV e o II a. C. Terá sido durante este período que este "poço" terá sido aberto.

Gontudo, falta ainda perceber a relação desta estrutura com o piso de cabana. Repare-se que a cota do referido piso correspondia quase à cota do fundo do "poço".

Conimbriga, 40 (2001) 37-64 
Pensamos que esta estrutura em poço se pode relacionar com o armazenamento de água ou terá mesmo funcionado como silo.

Mais tarde, talvez nos finais do séc. I/inícios do II, esta estrutura terá servido para depósito de restos de grandes recipientes (dolía), funcionando assim como fossa detrítica.

\subsection{A estratigrafia}

\subsubsection{Perfil estratigráfico Este/Oeste, parede Sul (quadrados Al a A5) (Est.VIII)}

Designado por Corte estratigráfico 1, compunha-se das seguintes camadas:

camada la - terras castanhas acinzentadas, soltas, com muitos fragmentos de telhas de meia-cana, louça vidrada, louça preta muito cozida, vidros, moedas. Trata-se de uma camada de remeximentos que podem ter sido profundos em algumas áreas;

camada $l b$ - bolsa de terras castanhas amareladas, soltas, com o mesmo conjunto de materiais arqueológicos da camada la. Trata-se de uma camada de remeximentos;

camada $l c$ - bolsa de terras castanhas escuras, soltas, carbonosas, com o mesmo conjunto de materiais arqueológicos da camada la. Trata-se de uma camada de remeximentos;

camada 2 - camada de terras castanhas amareladas, mediamente compactas, com alguns elementos pétreos de pequenas dimensões e espólio cerâmico proto-histórico - fragmentos cerâmicos manuais, brunidos e fragmentos cerâmicos feitos ao torno igualmente brunidos. Trata-se de um nível proto-histórico, da Idade do Ferro (sensivelmente a este nível encontrava-se o elemento dormente de mó);

camada 3 - terras castanhas claras, medianamente compactas, com muito elementos carbonosos e espólio semelhante ao da c.2. Trata-se de um nível proto-histórico, provavelmente da Idade do Ferro;

camada 4 - camada relativamente fina de terras castanho-amareladas, medianamente compactas, com muitos elementos carbonosos e espólio semelhante ao da c.2 e c.3. Corresponde ao nível do piso de barro da cabana/lareira identificado em BI (Idade do Ferro);

camada 5 - terras castanhas escuras, medianamente compactas, com muito elementos carbonosos e espólio semelhante ao das c.2, c.3

Conimbriga, 40 (2001) 37-64 
e c.4 (especial destaque para o fragmento com decoração estampilhada - suásticas - e cossoiros). Trata-se de um nível proto-histórico, cronologicamente integrável no séc. III/II a. C.;

camada 6 - Terras castanhas escuras, pouco compactas, com alguns elementos carbonosos e espólio semelhante ao das c.2, c.3 e c.4 (especial destaque para o fragmento de vaso decorado com fiada de incisões e impressões circulares). Corresponde ao interior da estrutura em poço;

camada 7 - Rocha granítica.

\subsubsection{Perfil estratigráfico Sul/Norte, parede Oeste (quadrados $\mathrm{Al} \mathrm{a} \mathrm{Cl)} \mathrm{(Est.} \mathrm{VIII)}$}

Designado por Corte estratigráfico 2, compunha-se das seguintes camadas:

camada 1 - terras cinzentas claras, soltas, com muitos fragmentos de telhas de meia-cana, louça vidrada, louça preta muito cozida, vidros. Trata-se de uma camada de remeximentos. Corresponde à c.la do corte 1 ;

camada 2 - terras castanhas acinzentadas, soltas, com o mesmo conjunto material da c.l ao qual se poderão acrescentar alguns fragmentos cerâmicos manuais. Trata-se de um enchimento de uma fossa de forma circular, cuja finalidade seria provavelmente detrítica, feita num período histórico indefinido talvez já no séc. XX, que terá furado os níveis proto-históricos, incluindo o piso de barro (c.4);

camada 3 - terras castanhas avermelhadas, medianamente compactas, com muito elementos carbonosos e espólio quase inexistente. Trata-se talvez de um nível medieval (Baixa Idade Média) correspondente aos restos do piso que encostava ao muro 5;

camada 4 - camada de barro argamassado de coloração vermelho-alaranjada, muitíssimo compacto. Corresponde a um piso de barro de cabana/lareira associado a cerâmicas manuais e feitas ao torno, muitas delas brunidas. Idade do Ferro;

camada 5 - terras castanhas escuras, mediamente compactas, com muito elementos carbonosos e espólio semelhante ao da c.4. Corresponderá à c. 5 do corte 1 . Trata-se de um nível da Idade do Ferro. 


\subsubsection{Perfil estratigráfico Sul/Norte, parede Este (quadrados $B T$ a AT) (Est. VII)}

Designado por Corte estratigráfico 3, compunha-se das seguintes camadas:

camada 1 - terras cinzentas claras, soltas, com muitos fragmentos de telhas de meia cana, louça vidrada, louça preta muito cozida e vidros. Foi igualmente recolhido um gargalo de unguentário em vidro verde-gelo, datável dos finais do séc. I/inícios do II d. C. Trata-se de uma camada de intensos remeximentos. Corresponde à c.l do corte 2;

camada 2 - terras castanhas escuras, pouco compactas. Trata-se do enchimento da estrutura em "poço". No topo e até cerca de $0,70 \mathrm{~m}$ de profundidade foram recolhidos fragmentos de dolia. Avançando em profundidade, foram exumados alguns fragmentos de cerâmicas de fabrico manual e a torno cronologicamente integráveis na Idade do Ferro;

camada 3 - Rocha granítica.

\subsection{Cultura material}

Foram recolhidos quase 800 fragmentos cerâmicos pertencentes a várias épocas.

Entre os materiais cerâmicos exumados destacam-se os que poderemos datar da Idade do Ferro (Ests. IX, X e XI).

Este conjunto enquadra-se num contexto estratigráfico específico (corte estratigráfico 2, camadas 4 e 5; corte estratigráfico 1, camadas 2,3, 4 e 5) que o separa do espólio exumado das camadas mais superficiais.

Morfologicamente encontramos três tipos de formas: bordos, asas (em número reduzido) e fundos.

Os bordos repartem-se entre as variantes esvasadas com lábios rectos ou ligeiramente arredondados, esvasadas formando uma aba soerguida ou horizontal de lábios maioritariamente rectos $\mathrm{e}$ bordos rectos de lábio arredondado.

O tratamento de superfícies é variável, apresentando a maioria vestígios de alisamento. Encontram-se também fragmentos com a superfície externa polida e a superfície interna alisada e fragmentos com ambas as superfícies polidas. Estes últimos coincidem com a tecnologia de fabrico a torno.

Conimbriga, 40 (2001) 37-64 
Tecnicamente identificamos cerâmicas de fabrico manual, constituindo este grupo a maioria do espolio recolhido; de fabrico por molde, técnica visível numa pequena percentagem do conjunto de fragmentos e, tal como referimos anteriormente, cerámicas de fabrico a torno.

As pastas apresentam elementos não-plásticos dos quais se destacam, numa análise macroscópica, o quartzo e a mica, variando a sua quantidade de acordo com o tipo de fabrico dos recipientes.

Por conseguinte, a maioria das pastas de recipientes produzidos manualmente contêm elementos de quartzo de médio e grande calibre e micas, muito abundantes em alguns recipientes, de pequeno e médio calibre, formando pastas porosas. Por outro lado, as pastas dos recipientes fabricados a torno são mais depuradas, de forma que apresentam e.n.p. de pequeno calibre em pastas muito compactas.

Por fim, será de destacar que foram exumados fragmentos de recipientes que sofreram cozeduras de tipo oxidante e outros com cozedura de cariz redutor. É igualmente de destacar que as cerâmicas com cozedura oxidante se encontram apenas nos fragmentos de fabrico manual.

De todo o conjunto de espolio cerâmico foram exumados apenas fragmentos com duas variações decorativas. Uma caracteriza-se pelo uso da técnica de estampilha em SS formando urna suástica sobre urna superficie alisada (Est. X). Outra, num recipiente com um tratamento de superfície mais rico, evidencia a existência de uma banda com incisões oblíquas que divide o colo da pança com círculos concêntricos impressos, formando triângulos (Est. IX). Esta última organização decorativa podemos encontrá-la no nível 3 do Castro de Cameixa [LOPEZ Cuevillas \& LORENZO FERnÁndeZ, 1986]. Este paralelo refere-se apenas aos três círculos concêntricos a formar triângulo, que no caso concreto se encontram associados a um motivo da tipología de Armando Coelho que aponta para a fase II ou III, com paralelos no Castro de Romariz [SILVA, 1986: est. LXXIV].

Foram ainda identificados alguns fragmentos de recipientes de grandes dimensões com cepillo interno.

Foi ainda recolhido um cossoiro e um fragmento de outro (Est. $\mathrm{X})$, que se enquadram no tipo $\mathrm{Al}$ da tipología de Armando Coelho [SILVA, 1986: Est. LXXXI]

Por fim, de entre o espólio exumado será de referir uma peça em quartzito, polida em todas as faces e com vestígios de uso. A esta peça atribuímos a função de afiador, visto o seu desgaste ser caracterizado por estrias finas paralelas.

Conimbriga, 40 (2001) 37-64 
O conjunto do espolio proto-histórico exumado, e após uma primeira análise, insere-se cronologicamente entre os séculos III e II a.C., na transição da Fase IIB para a IIIA de Armando Coelho [SILVA, 1986].

O espólio da época romana divide-se em cerâmico - cerâmica de construção [tegulae, imbrices, lateres, tijolos], cerâmica comum (doméstica), terra sigillata —, vitrico e lítico.

Quanto ao espólio cerâmico é de referir a concentração de cerâmica de construção junto ao muro 3 [A3] que indicia uma zona telhada pelo menos parcialmente. Por outro lado, foi junto ao muro 3 que foram recolhidas algumas das peças que nos podem datar a ocupação romana deste local na transição do séc. I para o século II da nossa era. Referimo-nos concretamente ao fragmento de terra sigillata hispânica decorado com círculos e o fragmento de vidro verde-gelo (Est. XII).

Uma análise, para já superficial, do conjunto de cerâmica doméstica recolhido bem como o fragmento de gargalo de unguentário em vidro verde-gelo deformado possivelmente pela acção do fogo, com bordo engrossado, com paralelos no Castro do Barbudo [MARTINS, 1989: IX-9] vem reforçar a ideia de que este espaço terá sofrido uma remodelação/reformulação num período de transição do séc. I para o II.

À Idade Média, provavelmente já nos seus finais — Baixa Idade Média - pertencerá a grande talha que estava enterrada no silo bem como alguns fragmentos de recipientes de louça negra que lhe estavam associados (Est. XII).

Como é óbvio, torna-se muito difícil de destrinçar as cerâmicas históricas, sobretudo as medievais, modernas e contemporâneas, uma vez que os níveis estratigráficos onde se encontravam estavam profundamente remexidos. Por outro lado, poucos são os estudos sobre as cerâmicas destes períodos, sobretudo cerâmicas modernas. Pela nossa parte, no relatório enviado ao IPA, foi apresentada uma relação dos materiais exumados, sumariamente descritos, cientes de que seria necessário aprofundar esse estudo.

Apresentamos o inventário do espólio que consideramos mais importante para este trabalho, uma vez que a apresentação dos quadros referentes às cerâmicas medievais e modemas/contemporâneas iria tornar este artigo muito extenso. Esses quadros podem ser consultados no relatório enviado ao IPA. Nesse sentido, para uma futura caracterização mais detalhada destas peças por parte de um investigador interessado, convém referir que todo o espólio exumado irá ser entregue na extensão do IPA em Viseu.

Conimbriga, 40 (2001) 37-64 


\subsection{Inventário}

Apresenta-se um inventário bastante sucinto sendo apenas referenciadas as peças mais significativas. Um inventário completo foi apresentado no relatório enviado ao IPA.

ESPÓLIO PROTO-HISTÓRICO

\begin{tabular}{|c|c|c|c|}
\hline N..$^{\circ}$ DE ORDEM & LOCALIZAÇÃO & DESCRIÇÃO & OBSERV. \\
\hline Pr. D. D. $99-12$ & $\begin{array}{l}\text { A2; y - 1,11m; } \\
\mathrm{x}-0,75 \mathrm{~m} ; \mathrm{z}^{\prime}-1,18 \mathrm{~m} ; \\
\mathrm{z}-1,70 \mathrm{~m}\end{array}$ & $\begin{array}{l}\text { frag. de cossoiro de } \\
\text { secção ovalada c/ } \\
\text { superfície alisada; }\end{array}$ & $\begin{array}{l}\text { fabrico manual. } \\
\text { Idade do Ferro }\end{array}$ \\
\hline Pr. D. D. 99 - 61 & A3. c.1a & $\begin{array}{l}\text { frag. de peça lítica, de } \\
\text { configuração paralelepi- } \\
\text { pédica, secção rectangu- } \\
\text { lar, polida em todas faces, } \\
\text { em matéria granitoide }\end{array}$ & Idade do Ferro \\
\hline $\begin{array}{l}\text { Pr. D. D. } 99-151 \\
-152-155\end{array}$ & A1'; c.2 & $\begin{array}{l}\text { frag. de púcaro de bordo } \\
\text { esvasado, lábio arredon- } \\
\text { dado, sup. brunidas, de- } \\
\text { coração em banda com } \\
\text { incisões oblíquas, no ar- } \\
\text { ranque do colo, impres- } \\
\text { sões de círculos concên- } \\
\text { tricos formando triângu- } \\
\text { los e asa de fita }\end{array}$ & $\begin{array}{l}\text { fabrico manual? } \\
\text { Idade do Ferro }\end{array}$ \\
\hline $\begin{array}{l}\text { Pr. D. D. } 99--154 \\
-185-196-585\end{array}$ & A1'; c.2 & $\begin{array}{l}\text { bordos esvasados, sup. } \\
\text { alisadas, lábio recto ou } \\
\text { ligeiram/ arredondado; }\end{array}$ & $\begin{array}{l}\text { fabrico manual } \\
\text { Idade do Ferro }\end{array}$ \\
\hline Pr. D. D. 99 - 391 & B1, c. 3 & $\begin{array}{l}\text { frag. de bordo de aba } \\
\text { horizontal, lábio redondo, } \\
\text { sup. alisada }\end{array}$ & $\begin{array}{l}\text { fabrico a torno } \\
\text { Idade do Ferro }\end{array}$ \\
\hline $\begin{array}{l}\text { Pr. D. D. } 99-124- \\
335-337-482- \\
487-491-492- \\
494-495 \text { a } 498 \\
-505-507-511 \\
\text { a } 513-515-517- \\
518-529-530-533 \\
-534-537 \text { a } 539- \\
542 \text { a } 552-554\end{array}$ & A2; c.5 & $\begin{array}{l}\text { frag. de panças, } \\
\text { sup. alisadas; }\end{array}$ & $\begin{array}{l}\text { fabrico manual } \\
\text { Idade do Ferro }\end{array}$ \\
\hline
\end{tabular}

Conimbriga, 40 (2001) 37-64 


\begin{tabular}{|c|c|c|c|}
\hline N. ${ }^{\circ}$ DE ORDEM & LOCALIZAÇÃO & DESCRIÇÃO & OBSERV. \\
\hline $\begin{array}{l}\text { Pr. D. D. } 99 \text { - } \\
502 \text { - } 514 \\
\text { Pr. D. D. } 99 \text { - } 774\end{array}$ & $\begin{array}{l}\text { A2; c. } 5 \\
\text { A2, c. } 5\end{array}$ & $\begin{array}{l}\text { bordos de aba soerguida, } \\
\text { lábio recto, sup polidas; } \\
\text { frag. de afiador em quart- } \\
\text { zito, vestígios de utiliza- } \\
\text { ção nas duas faces; }\end{array}$ & $\begin{array}{l}\text { fabrico manual } \\
\text { Idade do Ferro } \\
\text { Idade do Ferro }\end{array}$ \\
\hline Pr. D. D. 99 - 769 & A2, c. 5 & pertence ao vaso n. ${ }^{\circ} 184$ & fabrico manual \\
\hline $\begin{array}{l}\text { Pr. D. D. } 99-89137 \\
-140-353-358\end{array}$ & B1 & frag. de piso da cabana & - \\
\hline Pr. D. D. $99-184$ & $\begin{array}{l}\text { A } 2 ; Y-1,14 m ; X-0, \\
75 m ; Z-1,17 m ; \\
Z-1,69 m\end{array}$ & $\begin{array}{l}\text { frag. de pança c/ estampi- } \\
\text { lhas em SS, formando uma } \\
\text { fiada de suásticas com } 3 \\
\text { incisões horizontais por } \\
\text { cima e três por baixo; per- } \\
\text { tence a um grande recipiente. }\end{array}$ & $\begin{array}{l}\text { fabrico a torno } \\
\text { Idade do Ferro }\end{array}$ \\
\hline Pr. D. D. 99 - 461 & A3. c.1a & $\begin{array}{l}\text { frag. de peça lítica, de } \\
\text { configuração paralelepipé- } \\
\text { dica, secção rectangular, } \\
\text { polida em todas faces, em } \\
\text { matéria granitoide }\end{array}$ & - \\
\hline Pr. D. D. $99-179$ & $\begin{array}{l}\text { A2; y - 1,40m; x - 0,20 m; } \\
z^{\prime}-1,08 m ; z-1,60 m\end{array}$ & $\begin{array}{l}\text { cossoiro de configuração } \\
\text { circular c/ perfuração igual- } \\
\text { mente circular e superfície } \\
\text { alisada: Idade do Ferro }\end{array}$ & fabrico manual \\
\hline Pr. D. D. $99-16$ & A2, c. 5 & $\begin{array}{l}\text { frag. de pança c/ punciona- } \\
\text { mentos feitos c/ punção de } \\
\text { ponta romba, sup. alisadas; } \\
\text { pré-histórico - calcolítico? }\end{array}$ & fabrico manual \\
\hline
\end{tabular}

ESPOLIO ROMANO

\begin{tabular}{l|l|l|l}
\hline N. DE ORDEM & LOCALIZAÇÃO & DESCRIÇÃO & OBSERV. \\
\hline Pr. D. D. 99 - 19 & A3; base do muro 3 & frag. fundo de um prato. & $\begin{array}{l}\text { fabrico a torno } \\
\text { Época romana - } \\
\text { séc. I/II }\end{array}$ \\
\hline Pr. D. D. 99-20 & A3; base do muro 3 & $\begin{array}{l}\text { frag. de pança, com uma } \\
\text { incisão ondulada. }\end{array}$ & $\begin{array}{l}\text { fabrico a torno } \\
\text { Época romana - } \\
\text { séc. I/II }\end{array}$ \\
\hline
\end{tabular}

Conimbriga, 40 (2001) 37-64 


\begin{tabular}{|c|c|c|c|}
\hline N. ${ }^{\circ}$ DE ORDEM & LOCALIZAÇÃO & DESCRIÇÃO & OBSERV. \\
\hline Pr. D. D.99 - 343 & A3; base do muro 3 & $\begin{array}{l}\text { frag. de vidro, verde-gelo. } \\
\text { Arranque de asa?; }\end{array}$ & $\begin{array}{l}\text { Época romana - } \\
\text { séc. I/II }\end{array}$ \\
\hline Pr. D. D. $99-182$ & B2'; c.1 & $\begin{array}{l}\text { gargalo de unguentário em } \\
\text { vidro, verde-gelo. }\end{array}$ & $\begin{array}{l}\text { Época romana - } \\
\text { séc. I/II }\end{array}$ \\
\hline Pr. D. D. 99 - 287 & A3; base do muro 3 & frag. de asa de fita; & $\begin{array}{l}\text { fabrico a torno. } \\
\text { Época romana } \\
\text { - séc. I/II }\end{array}$ \\
\hline Pr. D. D. 99 - 186 & A3; base do muro 3 & $\begin{array}{l}\text { frag. de pança de taça } \\
\text { em sigillata hispânica } \\
\text { decorada com círculos } \\
\text { concêntricos. }\end{array}$ & $\begin{array}{l}\text { Época romana - } \\
\text { séc. I/II }\end{array}$ \\
\hline Pr. D. D. 99 - 188 & A3; base do muro 3 & $\begin{array}{l}\text { frag. }( \pm 1 / 4) \text { de elemento } \\
\text { girante de moinho manual; } \\
\text { superfície superior c/ leve } \\
\text { inclinação para o olho; su- } \\
\text { perfície de moagem direita } \\
\text { (ângulo } 2^{\circ} \text { ); olho circular; } \\
\text { lado ligeiramente convexo } \\
\text { e vertical; granito; raio: } \\
24 \mathrm{~cm} \text {; alt: } 7,5 \mathrm{~cm} \text {. }\end{array}$ & Época romana \\
\hline Pr. D. D. 99 - 772 & A3; base do muro 3 & $\begin{array}{l}\text { frag. }( \pm 1 / 4) \text { de elemento } \\
\text { girante de moinho manual; } \\
\text { superfície superior c/ leve } \\
\text { inclinação para o olho; } \\
\text { superfície de moagem } \\
\left.\text { direita (ângulo } 17^{\circ}\right) \text {; olho } \\
\text { circular; lado ligeiramente } \\
\text { direito e vertical; orifício } \\
\text { circular }(\varnothing 4 \mathrm{~cm} \text { ) lateral } \\
\text { cuneiforme c/ } 5,5 \mathrm{~cm} \text { de } \\
\text { profundidade; raio: } 13 \mathrm{~cm} \text {; } \\
\text { alt: } 17,5 \mathrm{~cm} \text {; granito. }\end{array}$ & Época romana \\
\hline Pr. D. D. 99 - 187 & $\begin{array}{l}\text { A1; x- } 105 \mathrm{~cm}, y-13 \mathrm{~cm} \\
\text { z- } 206 \mathrm{~cm}, \mathrm{z}^{\prime}-90 \mathrm{~cm}\end{array}$ & $\begin{array}{l}\text { elemento dormente de moinho } \\
\text { manual; base convexa; super- } \\
\text { fície de moagem convexa } \\
\left(\text { ângulo } 20^{\circ}\right) \text {; buraco central } \\
\text { circular troncocónico, c/ } 7 \mathrm{~cm} \\
\text { de profundidade; lado profun- } \\
\text { damente convexo; raio: }\end{array}$ & Época romana \\
\hline
\end{tabular}

Conimbriga, 40 (2001) 37-64 


\begin{tabular}{l|l|l|l}
\hline N. ${ }^{\circ}$ DE ORDEM & LOCALIZAÇÃO & DESCRIÇÃO & OBSERV. \\
\hline Pr. D. D. 99-190 & C1'; sup & $\begin{array}{l}19 \mathrm{~cm} \text {; alt: } 12 \mathrm{~cm} \text {; granito; } \\
\text { a base convexa faz supor } \\
\text { que estivesse enterrada } \\
\text { num piso; }\end{array}$ & \\
\hline & $\begin{array}{l}\text { placa circular }(\varnothing-37 \mathrm{~cm}) ; \\
\text { faces planas; alt: } 7 \mathrm{~cm} ; \text { em } \\
\text { granito; provável base de } \\
\text { recipiente de grandes } \\
\text { dimensões. }\end{array}$ & Época romana? \\
\hline
\end{tabular}

Surgiram, como foi já referido, dois fragmentos de lápides gravadas. O desenho das letras e a falta de pátina indiciam uma cronologia não romana talvez seicentista.

\section{Epígrafe n. $0^{\circ}$ 1:}

Placa em granito amarelo, encontrada inserida numa das paredes de um antigo edifício sito na Praça D. Duarte, 1 e 3, freguesia de Santa Maria de Viseu, em pleno coração do Centro Histórico da cidade de Viseu, actualmente guardada à entrada do referido edifício (foto 8).

De configuração paralelepipédica, encontra-se, infelizmente, mutilada tanto na base como num dos lados. A epígrafe foi ainda reaproveitada numa outra construção anterior, pois apresenta um encaixe de ferrolho no campo epigráfico. A face interior não foi preparada, o que pressupõe a sua primitiva inclusão numa parede.

O campo epigráfico não possui moldura tendo sido finamente polido.

As medidas que se apresentam são referentes às medidas máximas existentes: comprimento máximo - $52 \mathrm{~cm}$; altura máxima $-32 \mathrm{~cm}$; espessura - ?.

\section{$[\ldots]$ ELLVM/OP $[\ldots]$}

Altura das letras: 7,5 cm. Espaços: $1: 4,5 ; 2: 4,5 ; 3:$ ?

Conimbriga, 40 (2001) 37-64 
Paginação muito cuidada, notável distribuição das letras no espaço epigráfico. Traçado regular da letra, capital quadrada, bem geométrica e proporcionada.

\section{Epígrafe n. ${ }^{\circ}$ 2:}

Trata-se de um outro fragmento de uma placa em granito de grão fino, encontrada igualmente inserida na mesma parede da epígrafe n. $^{\circ} 1$, a uma cota inferior, encontrando-se actualmente exposta no mesmo sítio onde foi por nós vista pela primeira vez, hoje no $1 .^{\circ}$ andar do . $^{\circ} 1$ e 3 da Praça D. Duarte (foto 8).

De configuração paralelepipédica encontra-se também muito mutilada tanto na base e topo como nos lados. Um dos lados foi totalmente rebaixado tendo-se perdido para sempre a informação que conteria. Encontra-se virada ao contrário.

O campo epigráfico está finamente polido.

As medidas que se apresentam são referentes às medidas máximas existentes: comprimento máximo - 22,2 cm; altura máxima —35,5 $\mathrm{cm}$; espessura $-10 \mathrm{~cm}$.

$[\ldots] \mathrm{RC}[\ldots] / \mathrm{EV}$.

Altura das letras: $8 \mathrm{~cm}$. Espaços: 1: 4,7; 2: 4,7; 3: ?

Paginação muito cuidada, notável distribuição das letras no espaço epigráfico. Traçado regular da letra, capital quadrada, bem geométrica e proporcionada.

Pertenceria provavelmente à placa $\mathrm{n} .^{\circ} 1$.

\section{As Ruas do Gonçalinho, Escura e Prebenda 7}

No dia 05 de Março de 1999, a ArqueoHoje, Lda, foi contactada pela Câmara Municipal de Viseu para a indicação de um arqueólogo que acompanhasse as obras de abertura de valas para infra-estruturas

7 Este capítulo utiliza informações retiradas do relatório de autoria de Clara Portas Matias a quem agradecemos toda a colaboração prestada nos trabalhos da arqueologia urbana em Viseu.

Conimbriga, 40 (2001) 37-64 
subterrâneas e repavimentação da Rua do Gonçalinho, Rua da Prebenda e Rua Escura (Est. XV).

Após a devida autorização do Instituto Português de Arqueologia $^{8}$, os trabalhos de campo decorreram entre 08 de Março e 10 de Maio do ano de 1999.

A existência de estruturas arqueológicas - insula - escavada pela Dr. ${ }^{a}$ Helena Frade em 1997, na esquina da Rua da Prebenda com a Rua do Gonçalinho, o achado de um busto romano na R. do Gonçalinho [Coelho, Carvalho, 1987], e a proposta de Jorge de Alarcão que faz passar pela R. Direita o cardo maximus e pela R. do Gonçalinho/R. Escura o decumanus maximus colocaram as áreas a acompanhar com um potencial risco de achados arqueológicos [ALARCÃO, 1989].

De acordo com o pedido de autorização de trabalhos arqueológicos, estes foram da responsabilidade de Pedro Manuel Sobral de Carvalho e de Clara Portas Matias.

O primeiro acompanhou e é responsável pelos trabalhos efectuados em parte da Rua do Gonçalinho - lanço entre a esquina com a Rua João Mendes e Av. Capitão Silva Pereira, lanço entre a esquina norte da R. da Prebenda e Rua Direita - uma pequena extensão da vala da Rua da Prebenda (a Sul) e a Rua Escura.

A Dr. ${ }^{a}$ Clara Portas responsabilizou-se pelos trabalhos efectuados em parte da Rua do Gonçalinho - lanço entre a esquina da Av. Capitão Silva Pereira e a Rua da Prebenda - e quase toda a Rua da Prebenda.

O lanço entre a esquina Norte da Rua da Prebenda e Rua Direita forneceu os dados arqueológicos mais inesperados e importantes.

Efectivamente, junto à porta do $\mathrm{n} .{ }^{\circ} 15 \mathrm{~A}$ foi possível observar e escavar parte de um piso de cabana proto-histórica.

Este piso é estruturalmente semelhante ao descoberto na Praça D. Duarte. Trata-se de um piso constituído por barro vermelho/alaranjado com 0,10 m de espessura (fotos 10 e 11).

Associado a este piso foi exumado um conjunto de fragmentos cerâmicos manuais, lisos. As superfícies dos fragmentos são maioritariamente alisadas e integram-se cronologicamente nos finais da Idade do Bronze/Idade do Ferro (vide relação dos materiais).

Sobre este piso encontrava-se um nível de terras saibrentas com materiais romanos e medievais.

$8 \operatorname{Proc}^{\circ}$ 99/1 (291), of ${ }^{\circ}$ 1199, datado de 23 de Março de 1999.

Conimbriga, 40 (2001) 37-64 
$\mathrm{O}$ piso teria primitivamente cerca de $1,10 \mathrm{~m}$ de largura no sentido E-O, não tendo sido possível determinar esta medida para Norte, pois encontrava-se a parede da casa.

Ao longo do rasgo desta rua apareceram, fora de contexto, alguns fragmentos cerâmicos modernos, medievais e romanos com especial destaque para algumas sigillatas hispânicas Drag. 15/17.

Houve sítios em que o saibro estava a pouco mais de $0,50 \mathrm{~m}$ de profundidade. É o caso do local entre o $n^{\circ} 30$ e o $\mathrm{n}^{\circ} 34$, onde o saibro estava a $0,70 \mathrm{~m}$ de profundidade.

$\mathrm{Na}$ Rua do Gonçalinho, lanço entre a esquina da Rua João Mendes e a Av. Capitão Silva Pereira, interessa o registo de um conjunto de lajes de grandes dimensões, que se apresentava bem conservado junto à porta n. ${ }^{\circ} 82$ (Est. XVI; foto 12). Trata-se de três lajes com uma largura que variava entre os $0,40 \mathrm{~m}$ e os $0,50 \mathrm{~m}$, que apresentavam precisamente a mesma cota. A $1,20 \mathrm{~m}$ a Este encontrava-se uma outra laje de menores dimensões, que terá pertencido, no entanto, a este conjunto.

Relacionadas com este lajeado estariam outras duas lajes, de menores dimensões, junto ao n. ${ }^{\circ} 94$ (Z'-0,90m).

Este lajeado poderá corresponder ao primitivo arruamento romano - decumanus maximus - cujos vestígios foram igualmente detectados pela Dr. ${ }^{\text {a }}$ Clara Portas no lanço da R. do Gonçalinho junto à Rua da Prebenda.

Os trabalhos arqueológicos desenvolvidos pela $\mathrm{Dr}^{3}$ Clara Portas Matias $^{9}$ permitiram a identificação de importantes estruturas da época romana. Segundo esta investigadora, em frente à Pastelaria Império, ao levantarem o empedrado, surgiram duas pedras largas que constituíam a tampa de uma conduta (Ests. XVII, XVIII e XIX).

Sob o velho cano de água iam aparecendo por entre a terra já em tempos remexida, diversos fragmentos de tegulae, de lateres e um ou outro de cerâmica comum.

No espaço considerado Gonçalinho 2 (G.2) pôs-se a descoberto, à cota $0,95 \mathrm{~m}$, uma coroa de pedras, bem consolidadas, que denunciavam a existência de um pavimento calcetado, já em parte destruído.

9 Convém salientar que se tratou de trabalhos repletos de dificuldades de vária ordem, como rebentamento de canos, pressões de empreiteiros, exiguidade do espaço de observação, não acatação das sugestões do arqueólogo(a)... Agradecemos sinceramente o trabalho desenvolvido de uma forma capaz e eficiente pela Dr* Clara Portas Matias.

Conimbriga, 40 (2001) 37-64 
Sob a canalização antiga, foram identificadas numerosas pedras faceadas envolvidas por terra barrenta escurecida, bem como por cinzas e muitas partículas de carvão formando por vezes bolsas bem definidas.

Mais alguns metros para poente (Gonçalinho 3) em frente à porta de entrada do prédio sondado em 199710, as pedras de derrube apareciam em profusão. Verificou-se então que as mesmas tinham tombado sobre o lajeado largo de uma calçada (Est. XX).

A terra que envolvia as pedras e se sobrepunha ao lajeado continuava revelando bastantes partículas de carvão, tendo-se exumado fragmentos de tegulae com abundância, alguns fragmentos de cerâmica comum e pregos. Era total a ausência de imbrices.

Continuando a sondagem para poente, já próximo da esquina da Rua da Prebenda (Gonçalinho 4), encontraram-se ainda pedras da derrocada, mas de onde a onde, algumas de maiores dimensões, provavelmente in situ.

Frente à esquina da casa sondada em 1997, quando esta faz gaveto com a Rua da Prebenda, descobriu-se um conjunto de pedras de considerável volume, com aparelho, dando a entender terem formado o cunhal de qualquer estrutura, o qual também já revela a destruição por obras passadas.

Em Gonçalinho 5, colocou-se a descoberto parte de uma estrutura pétrea bastante encorpada, também com fragmentações consequência de antigos trabalhos. O material exumado resumiu-se a fragmentos de cerâmica de construção.

A Prebenda 1 (P.l) inicia-se junto ao cunhal da casa sujeita a sondagens em 97. Logo aqui, abaixo da canalização velha, identificou-se um lajeado largo (Est. XXI).

Problemas com a ruptura do cano obrigaram a retornar a investigação cerca de 11 metros mais à frente, começando a encontrar abaixo da canalização inúmeras pedras de derrube envolvidas por terra muito escura e grande quantidade de fragmentos de tegulae, de lateres bastante grossos e fragmentos de cerâmica comum (P. 2).

Depois de se retirarem as pedras, a terra tomou-se ainda mais escura com fortes vestígios de carvão e de cinzas. Esta era uma camada rela-

${ }^{10}$ Edifício onde foram realizados trabalhos arqueológicos conduzidos pela $\mathrm{Dr}^{3}$ Helena Frade. Foram então identificados vestígios de uma insula.

Conimbriga, 40 (2001) 37-64 
tivamente pouco espessa, pois na sequência da escavação surgiram, poucos centímetros abaixo, vestígios de um pavimento em opus signinum.

Esta situação prevaleceu por cerca de 20 metros ao longo do quarteirão e o opus signinum chegou para lá do ponto onde o alçado faz uma inflexão (cunhal com base moldurada - R 3).

A deposição das camadas de terra mantinha-se continuando a aparecer cinzas e carvões sobre o opus. Deste estracto exumaram-se alguns fragmentos de cerâmica comum — fundos de dolia, louça de cozinha, o pé de uma tacinha de sigillata hispânica (Drag. 27?), um outro pequeno fragmento de taça, provavelmente sigillata itálica, elementos cerâmicos em forma de losango com diagonais de 8 e $5 \mathrm{~cm} \mathrm{e} 3 \mathrm{~cm}$ de espessura.

Para além de P. 3, a fisionomia da vala começou a alterar-se. As pedras pequenas rareavam, aparecendo num outro contexto, associadas a outras de maiores dimensões, formando reduzidos vestígios de estruturas organizadas, só minimamente identificáveis. No entanto, ainda se detectavam vestígios de carvão na terra que as envolvia.

Já em P.4 desapareceu o opus signinum e só se descobriu um conjunto pétreo que sugere um lastro de muro.

Avançando para o topo sudoeste da Rua encontrou-se em P.5 um alinhamento de pedras e uma maior atravessada como que travando ou reforçando esta estrutura de difícil interpretação.

À medida que se aproximava o fim deste quarteirão de casas, a terra mudou de cor e de textura, tornando-se saibrenta, sem vestígios de estruturas e ausência total de espólio arqueológico.

É evidente que tem de se estabelecer uma relação muito próxima entre os achados das Ruas do Gonçalinho e da Prebenda e a insula da casa sondada em 1997.

Provavelmente o lajeado largo da Rua do Gonçalinho corresponderia a uma calçada romana apontada quase perpendicularmente à Rua Direita de hoje. Se esta fosse o cardo maximus (seg. Alarcão), então teríamos na Rua do Gonçalinho o pavimento do decumanus maximusl

A derrocada das pedras sobre a calçada seriam das paredes da in-

sula ou de outro edifício que se situaria no lado oposto da calçada?

Não chegamos a concluir se a Rua da Prebenda coincidiria com algum acesso à calçada. Cremos que poderia ter sido, antes, um pátio rodeado de outras estruturas habitacionais ou anexos dada a existência do pavimento em opus signinum e os vestígios de alicerce (?).

Em relação à Rua Escura e ao troço da Rua Direita que faz "coto-

Conimbriga, 40 (2001) 37-64 
velo" com a Rua do Gonçalinho, não foram identificados quaisquer vestígios arqueológicos dignos de nota.

Efectivamente, o substrato de base encontra-se a pouca profundidade, havendo sítios, como o ponto de cota mais alta da R. Escura, em que a rocha aparece cerca de $20 \mathrm{~cm}$ abaixo do topo da calçada.

A Rua Direita foi muito remexida com a instalação de uma grande conduta de esgotos construída há cerca de 40 anos.

\subsection{Cultura material}

\subsection{Inventário}

Apresentamos apenas o inventário das peças mais relevantes para este estudo.

\begin{tabular}{l|l|l|l}
\hline N. ${ }^{\circ}$ DE ORDEM & LOCALIZAÇÃO & DESCRIÇÃO & OBSERV. \\
\hline $\begin{array}{l}\text { R. do Gonçalinho. } \\
99-36-47-62\end{array}$ & $\begin{array}{l}\text { Piso junto ao 15 A; } \\
\text { entre o piso. }\end{array}$ & $\begin{array}{l}\text { frag. de fundo de } \\
\text { base recta. }\end{array}$ & $\begin{array}{l}\text { fabrico manual. } \\
\text { Idade do Ferro }\end{array}$ \\
\hline $\begin{array}{l}\text { R. do Gonçalinho. } \\
99-40\end{array}$ & $\begin{array}{l}\text { Piso junto ao } 15 \mathrm{~A} ; \\
\text { entre o piso. }\end{array}$ & $\begin{array}{l}\text { frag. de bordo recto } \\
\text { de lábio redondo, sup. } \\
\text { alisadas. }\end{array}$ & $\begin{array}{l}\text { fabrico manual } \\
\text { Idade do Ferro. }\end{array}$ \\
\hline $\begin{array}{l}\text { R. do Gonçalinho. } \\
99-66\end{array}$ & $\begin{array}{l}\text { Piso junto ao } 15 \mathrm{~A} ; \\
\text { entre o piso. }\end{array}$ & $\begin{array}{l}\text { frag. de bordo esvasado } \\
\text { de aba soerguida e lábio } \\
\text { ligeiramente arredondado. }\end{array}$ & $\begin{array}{l}\text { fabrico manual. } \\
\text { Idade do Ferro. }\end{array}$ \\
\hline $\begin{array}{l}\text { R. do Gonçalinho. } \\
99-108-103-111\end{array}$ & $\begin{array}{l}\text { frags. de bordos de } \\
\text { sigillata hispânica } \\
\text { Drag. 15/17 }\end{array}$ & $\begin{array}{l}\text { frag. de arranque de asa } \\
\text { de rolo, sup. alisadas, } \\
\text { época romana? }\end{array}$ & fabrico a torno \\
\hline $\begin{array}{l}\text { R. da Prebenda. } \\
99-23\end{array}$ & Sem contexto & & \\
\hline
\end{tabular}

Conimbriga, 40 (2001) 37-64 


\section{Conclusões}

Os trabalhos arqueológicos desenvolvidos na Praça D. Duarte, n. ${ }^{\circ} 1$ e 3 e Ruas do Gonçalinho, Escura e Prebenda revelaram importantes resultados sobre a origem e historia da cidade de Viseu.

Desde há muito que a maioria dos autores que escreveram sobre Viseu colocam a sua origem num castro pré-romano [COELHO, 1941; GIRÃO, 1925; RIBEIRO, 1971; VALE, 1971]. Contudo, as evidências arqueológicas que comprovassem a sua existência resumiam-se ao achado de um ou outro machado de pedra polida [CoELho, 1943]. Todos estes autores basearam a teoria sobretudo na posição topográfica que o morro da Sé assume.

Deste modo, a identificação dos pisos de cabana, bem como o espólio exumado da Idade do Ferro, são as primeiras provas arqueológicas de que, de facto, existiu um povoado pré-romano no morro da Sé.

No entanto, há ainda um outro facto que importa salientar: o achado de um fragmento cerâmico com decoração formada por fiadas de incisões feitas com ponta romba. Trata-se de um elemento datável talvez do Calcolítico, que virá recuar a ocupação deste local a um período bastante anterior do que até aqui era suposto. Outros elementos materiais que podem reforçar esta evidência é o achado de um fragmento de lâmina de sílex na R. da Prebenda, bem como o machado achado na cripta da Sé [COELHO, 1950] ou o machado em anfibolito achado nos entulhos da casa na Rua do Carvalho, $\mathrm{n} .^{\circ} 15,16$ e $17^{11}$.

Assim, a primeira ocupação do morro onde hoje se encontra a parte antiga da cidade de Viseu remontará talvez ao Calcolítico (finais do IV. $^{\circ}$ a finais do III. $^{\circ}$ milénio A. C.). Tratar-se-ia provavelmente de um pequeno sítio de habitat, onde se ocupariam preferencialmente os abrigos rochosos.

Os registos arqueológicos de que actualmente dispomos não incluem elementos materiais do Bronze Antigo/Médio.

Assim, reportando-nos apenas aos indícios arqueológicos disponíveis, podemos afirmar com segurança que entre o séc. VI e o séc. II A.C. o morro da Sé sofreu uma ocupação intensiva.

11 Trabalhos arqueológicos da ARQUeOHOJE, a Ldda sob responsabilidade da $\operatorname{Dr}^{3}$ Clara Portas Matias; relatório aprovado pelo IPA (ofício. 97/1(393), 2332 datado de 16 de Julho de 1998. Trata-se de um machado em anfibolito de contorno rectangular, faces planas, bordos de eixos ligeiramente convergentes, gume convexo assimétrico, secção rectangular; totalmente polido.

Conimbriga, 40 (2001) 37-64 
O achado de 3 fragmentos cerâmicos manuais no edifício da R. Grão Vasco, n. ${ }^{\circ} 29$ e 31 em $1998^{12} 13$ fazia já supor a existência de urna ocupação proto-histórica.

A identificação dos pisos e do conjunto de materiais que agora se apresentam vêm demonstrar de forma inequívoca uma ocupação da Idade do Ferro, cronologicamente inserível entre o séc. VI e o séc. II A.C., na transição da Fase IIB para a Fase IIIA de Armando Coelho [SILVA, 1986]13.

A extensão deste núcleo habitacional deveria ter sido bastante ampla, estendendo-se pela encosta S. e SE., uma vez que a NO. e a N. o terreno, mais acidentado, é recortado por ravinas e escarpas abruptas. Uma intervenção arqueológica efectuada nessa zona Norte — Fábrica da Igreja Paroquial de Santa Maria, Rua Silva Gaio, n. ${ }^{\circ} 41^{14}$ - comprovou efectivamente a ausência de vestigios arqueológicos.

Quanto à ocupação romana, as evidências materiais apontam para uma presença intensa na segunda metade do séc. I/ princípios do II. Este facto havia já sido constatado por João Vaz nas escavações que executou na Praça D. Duarte, junto à Sé de Viseu [VAZ, 1996]. Não existe, por isso ainda a comprovação da fundação da cidade romana por Augusto. Temos, no entanto, cada vez mais dados que nos asseguram que Viseu seria capital de civitas na época de Cláudio (comprovado igualmente pelos achados recentes do Antigo Mercado 2 de Maio).

O muro romano identificado na Praça D. Duarte, n. ${ }^{\circ} 1$ e 3 , bem como os materiais exumados, apontam para a existência de um compartimento de dimensões modestas provavelmente relacionado com um espaço onde se armazenavam produtos em talhas (azeite e vinho) e alfaias (mós manuárias entre outros).

Os vestígios romanos da Rua do Gonçalinho e Prebenda são bastante limitados, pois o espaço disponível de intervenção era diminuto.

12 Trabalhos arqueológicos da ARQUEOHOJE, Ld ${ }^{\mathrm{a}}$, sob a responsabilidade da $\mathrm{Dr}^{3}$ Clara Portas Matias; relatório aprovado pelo IPA (ofício 97/1(313), 1489 datado de 9 de Abril de 1999).

13 Quando efectuávamos às últimas correcções deste trabalho, levávamos a cabo escavações arqueológicas no Antigo Mercado 2 de Maio. Os resultados confirmam, por datação relativa aos materriais cerâmicos exumados, o recuo da ocupação proto-histórica de Viseu aos inícios do Io milénio.

14 Trabalhos arqueológicos da ARQUEOHOJE, Lda ${ }^{\mathrm{a}}$, sob a responsabilidade da $\mathrm{Dr}^{3}$ Clara Portas Matias; relatório aprovado pelo IPA.

Conimbriga, 40 (2001) 37-64 
Contudo, a identificação do lajedo na R. do Gonçalinho faz supor um eixo viário que corresponderá certamente ao decumanus maximus.

Os restantes vestígios distribuidos pela Prebenda vêm comprovar que se trata de uma zona intensamente ocupada na época romana. Pena é que não fosse autorizado o alargamento da área intervencionada, pois ficaríamos a perceber a que estruturas pertencem os achados agora dados à estampa.

$\mathrm{Na}$ Praça D. Duarte, n. ${ }^{\circ} 1$ e 3, foram identificados igualmente alguns dados sobre a ocupação medieval. $O$ achado de uma enorme talha enterrada, junto a um muro de modestas dimensões bem como de um piso argamassado faz-nos colocar a hipótese da existência de um espaço aberto - pátio - relativamente pequeno. Assim, a habitação medieval deveria estender-se para Este. Futuros trabalhos poderão comprovar esta teoria.

Os níveis modernos/contemporâneos encontravam-se muito remexidos, havendo por isso bastante dificuldade em separar os materiais recolhidos. No entanto, podemos adiantar que terá sido no final do séc. XIX que o edifício se terá aproximado das dimensões actuais. O muro 1 terá resultado de aumento para Este da casa que terá sofrido um incêndio. Interessará observar, em futuras escavações, se este incêndio se terá estendido a outras casas do núcleo habitacional.

\section{Bibliografia}

AlarCão, Jorge de (1989), A cidade romana de Viseul Câmara Municipal de Viseu.

CARVAlho, Pedro Sobral de (1987), Viseu: apontamentos arqueológicos da cidade e seus limites, trabalho apresentado à cadeira de Técnicas de Investigação Arqueológica (policopiado).

Coelho, José (1941), Beira Histórica, arqueológica e artística. Memórias de Viseu (arredores) l.A freguesia do Salvador e o extinto concelho do Barreiro, Viseu.

Coelho, José (1943), Centro importante na época romana (Castro pré-romano de Viseu), Congresso Luso-Espanhol para o Progresso das CiênCias, $4 .{ }^{\circ}$ Porto, 7a Secção, CiênCias HistóRICAS E Filológicas, Porto, Associação para o Progresso das Ciências, pp. 162-169.

CoElHo, José (1950), Três templos romanos, XIII CONGRESSO LuSO-ESPANHOL PARA O Progresso DAS CIÊNCIAS, Tomo VIII, 7a Secção, CiÊNCIAS HistóRICAS E FILOLÓGICAS, Lisboa, pp. 350-372.

GIRÃo, A. de Amorim (1925), Viseu. Estudo de uma aglomeração urbana, Coimbra

Lopez Cuevillas, Florentino; Lorenzo Férnandez, Xaquín (1986), Castro de Cameixa - campañas 1944-46, Arqueoloxia/Memorias, Santiago de Compostela.

Conimbriga, 40 (2001) 37-64 
MARTINs, Manuela (1989), O Castro de Barbudo, Vila Verde. Resultados das campanhas realizadas entre 1983 e 1985, "Cadernos de Arqueologia - Monografias , 3, Braga.

Ribeiro, Orlando (1971), Em torno das origens de Viseul "Revista Portuguesa de Historia”, Coimbra, 13, pp. 211-229.

Silva, Armando Coelho Ferreira da (1986), A Cultura Castreja no Noroeste de Portugal Museu Arqueológico da Citânia de Sanfins, Paços de Ferreira.

VAle, A. de Lucena e (1971), Em torno das origens de Viseul "Beira Alta , Viseu, 30(2), 254-277.

VAZ, João L. Inés (1997), A Civitas de Viseu - Espaço e Sociedade, Viseu

VAZ, João L. Inés (1996), Linhas urbanisticas de Viseu na época romana, Los orígenes de la ciudad en el noroeste hispánico, Actas del Congreso Internacional, Lugo, pp. 393-408.

Conimbriga, 40 (2001) 37-64 


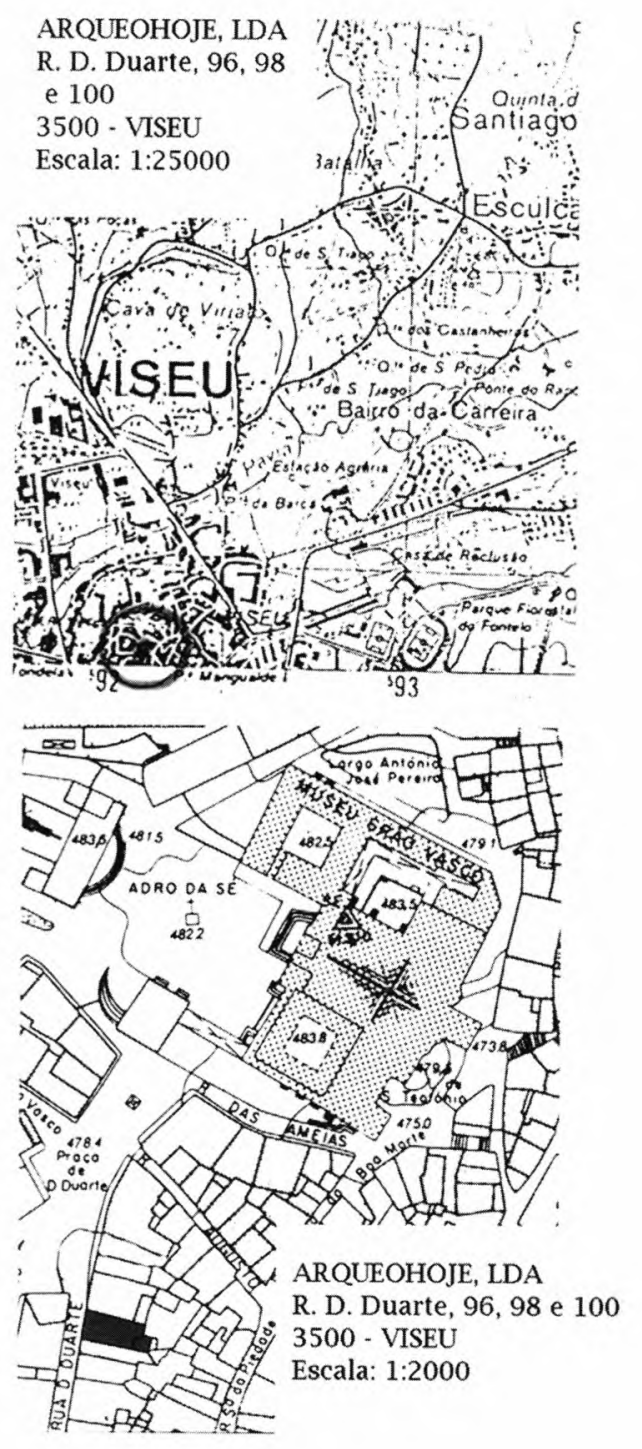


EST. II

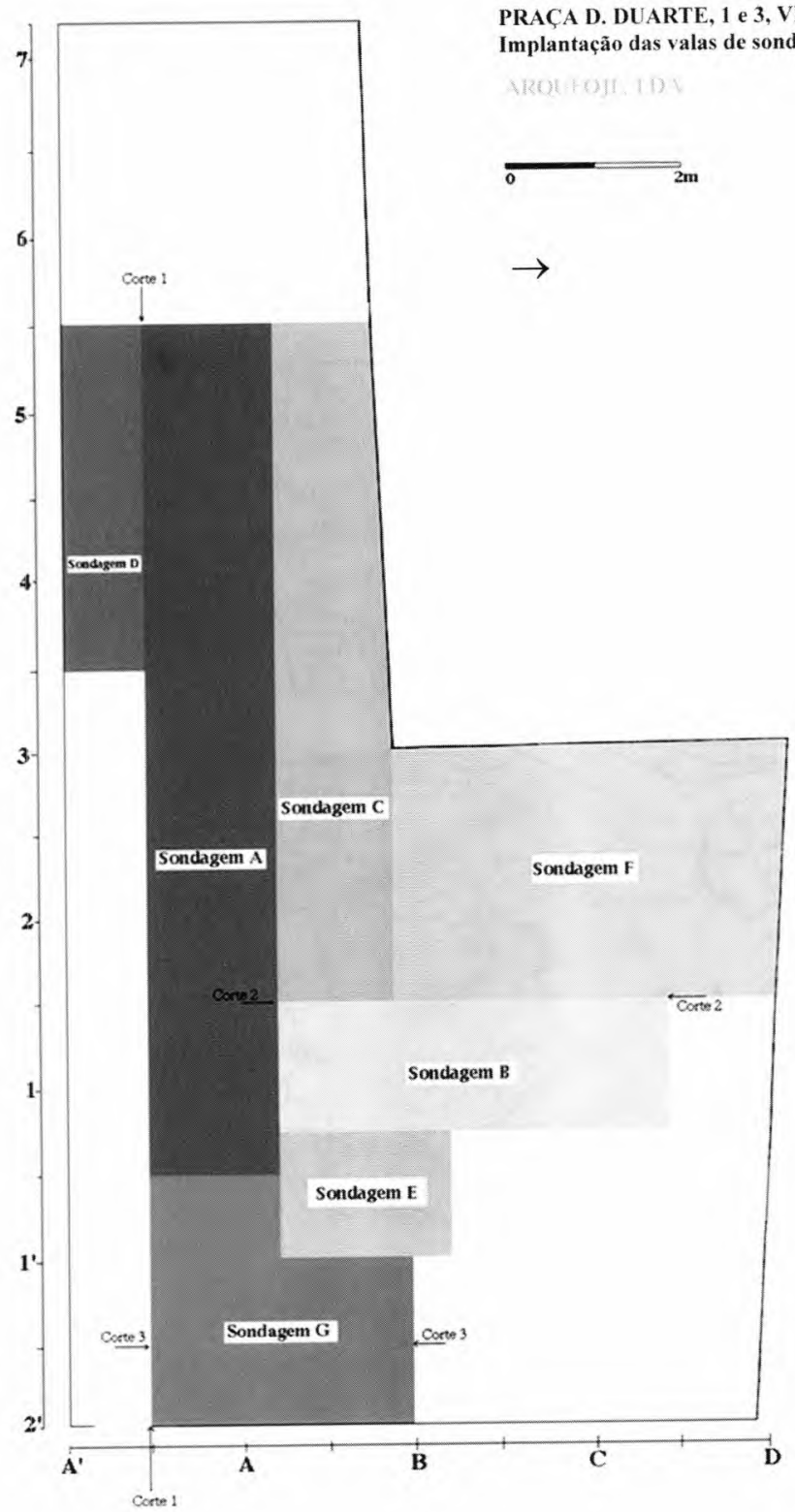


EST. Ill

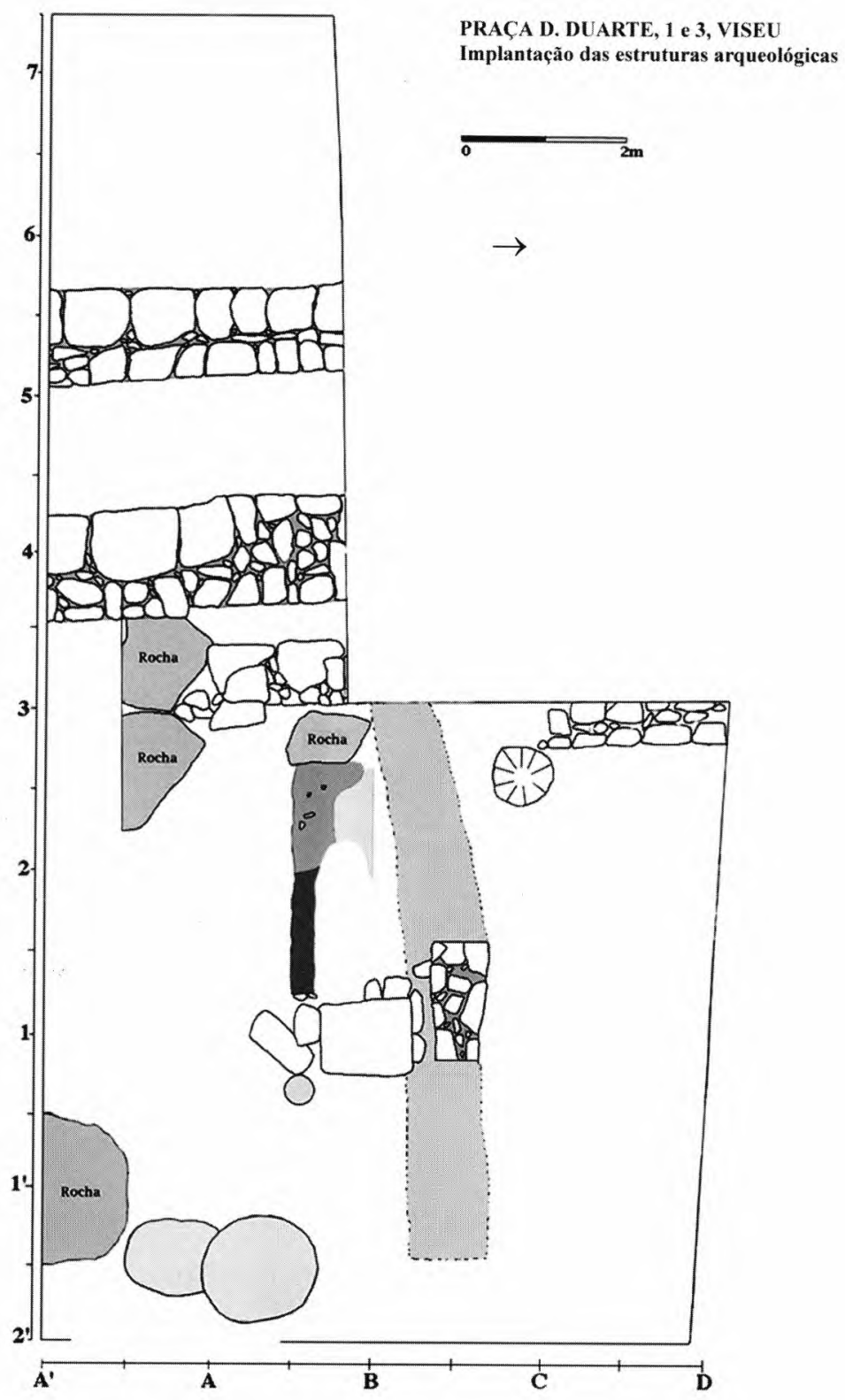


EST. IV

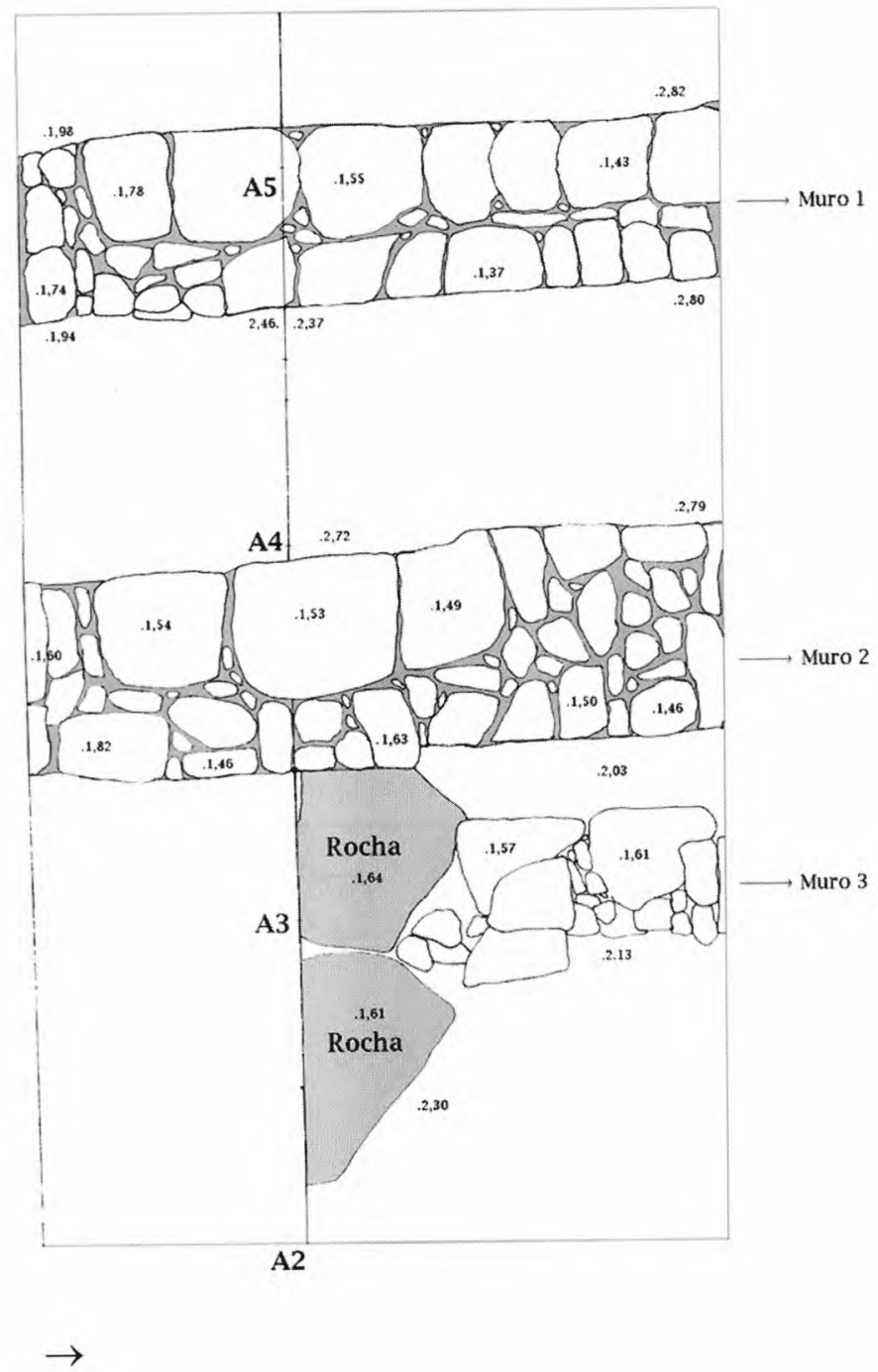

PRAÇA D. DUARTE, 1 e 3, VISEU

Planta dos muros 1,2 e 3

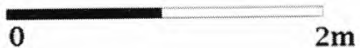


EST. V

PRAÇA D. DUARTE, 1 e 3, VISEU

Muro 5

Diso de baro argamassado

In forsa onde se encontrava uma tatha (silo)
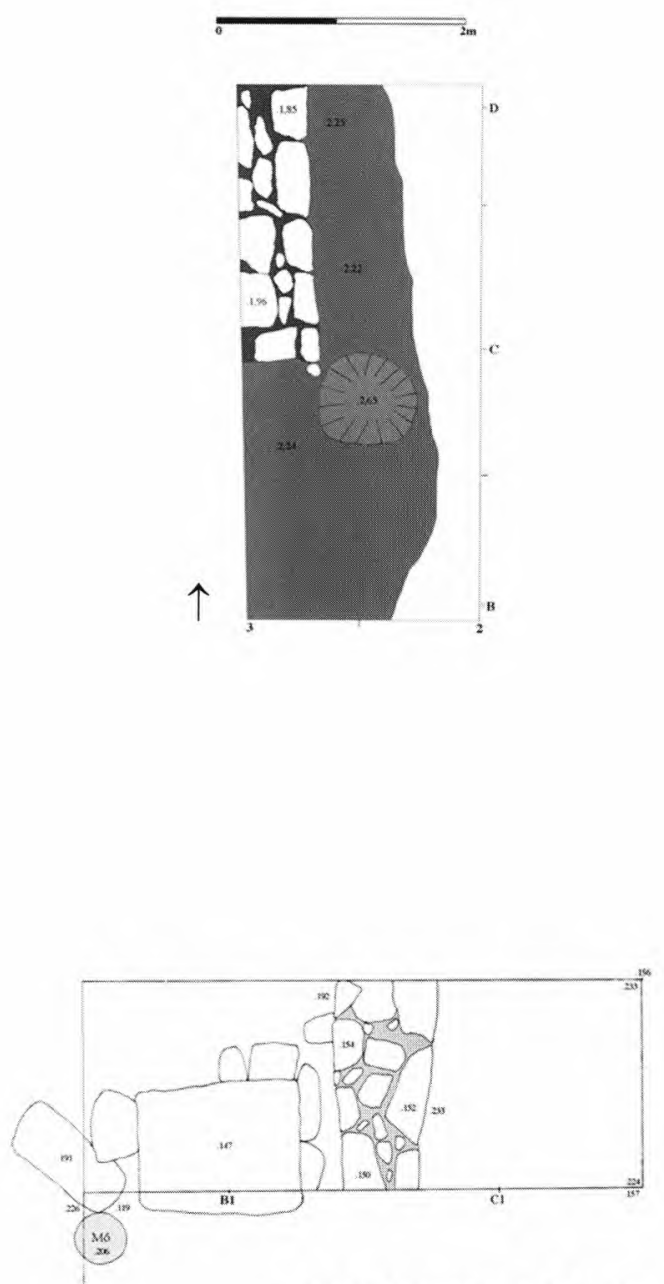

PRACA D. DUARTE, 1 e 3, VISEU

Planta da Vala B

$\rightarrow$

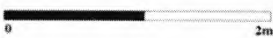




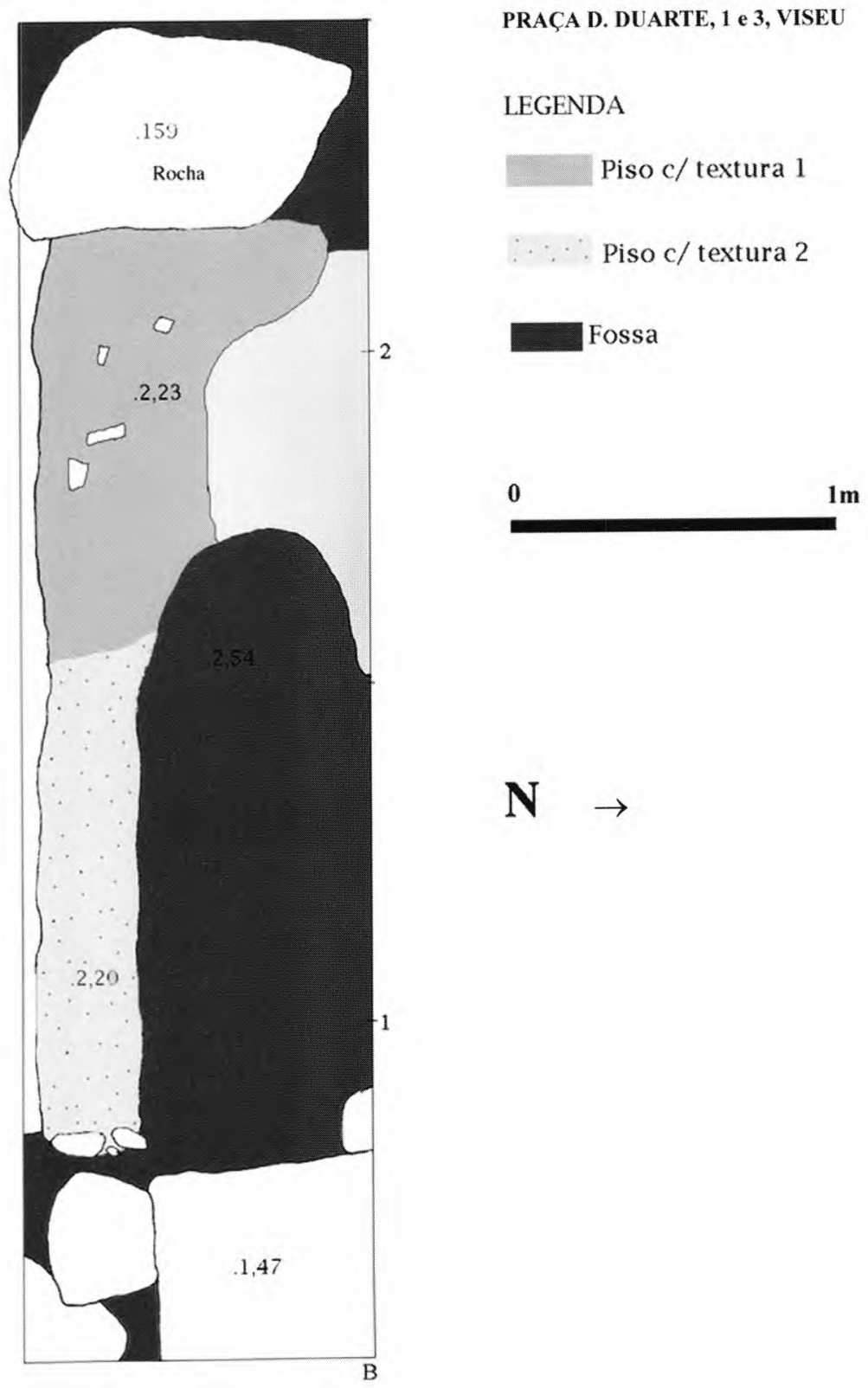


PRAÇA D. DUARTE, 1 e 3, VISEU / Sondagem G



$\mathbf{N} \rightarrow$

PRAÇA D. DUARTE, 1 e 3, VISEU / Corte 3

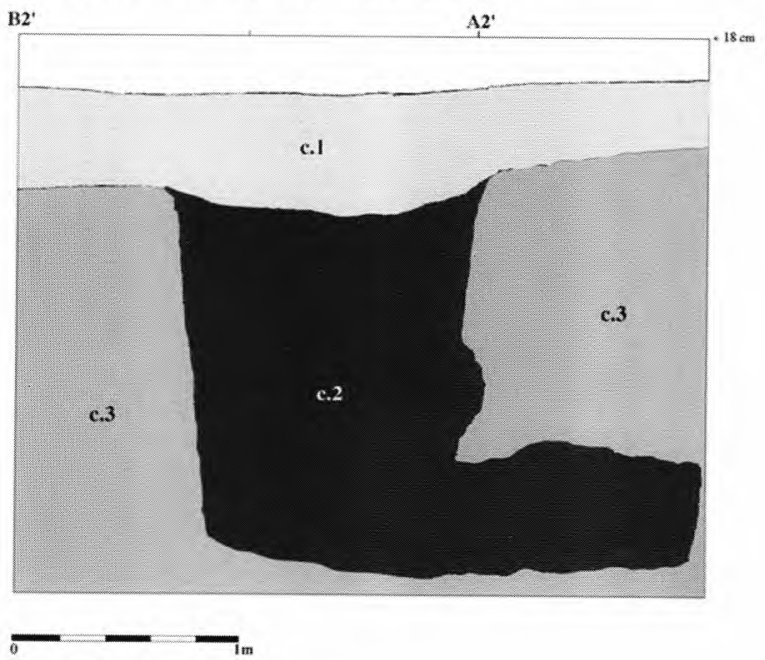



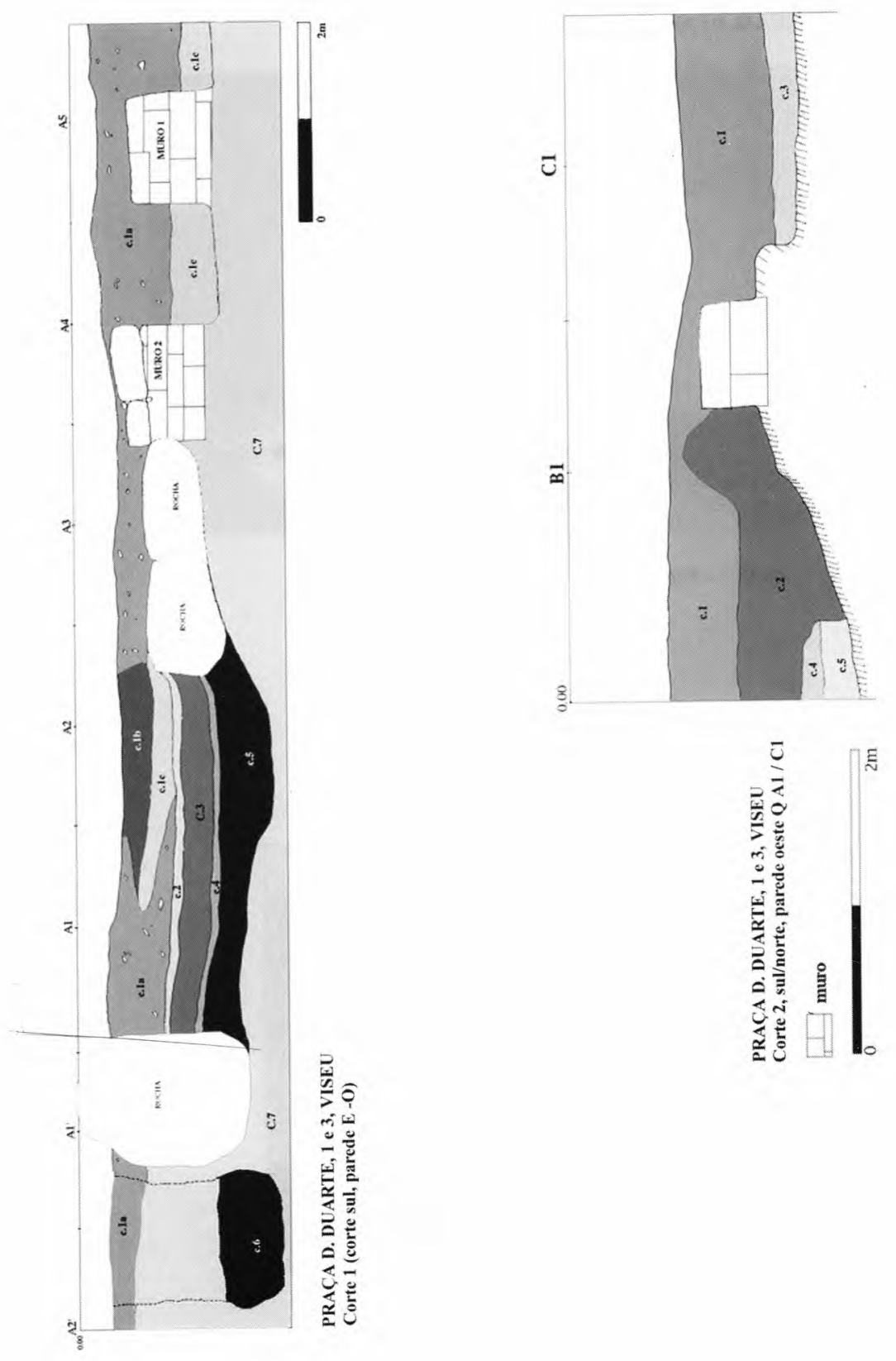
EsT. IX
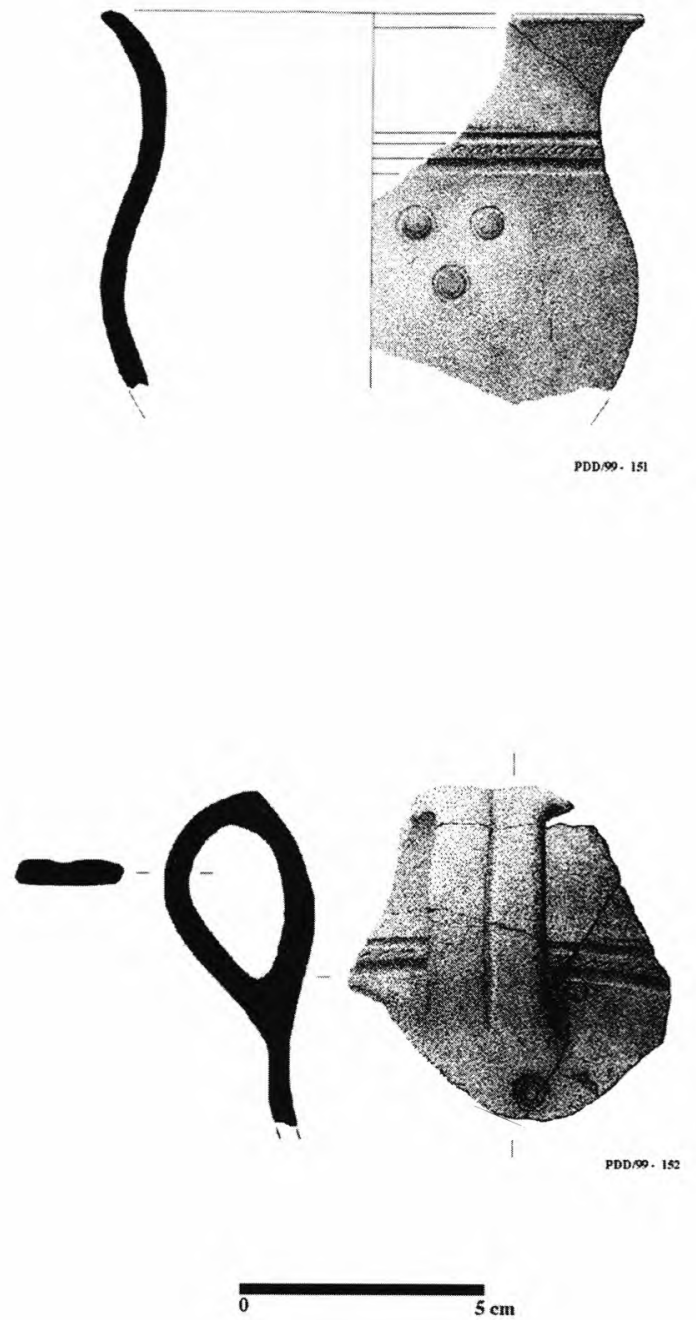
EST. X
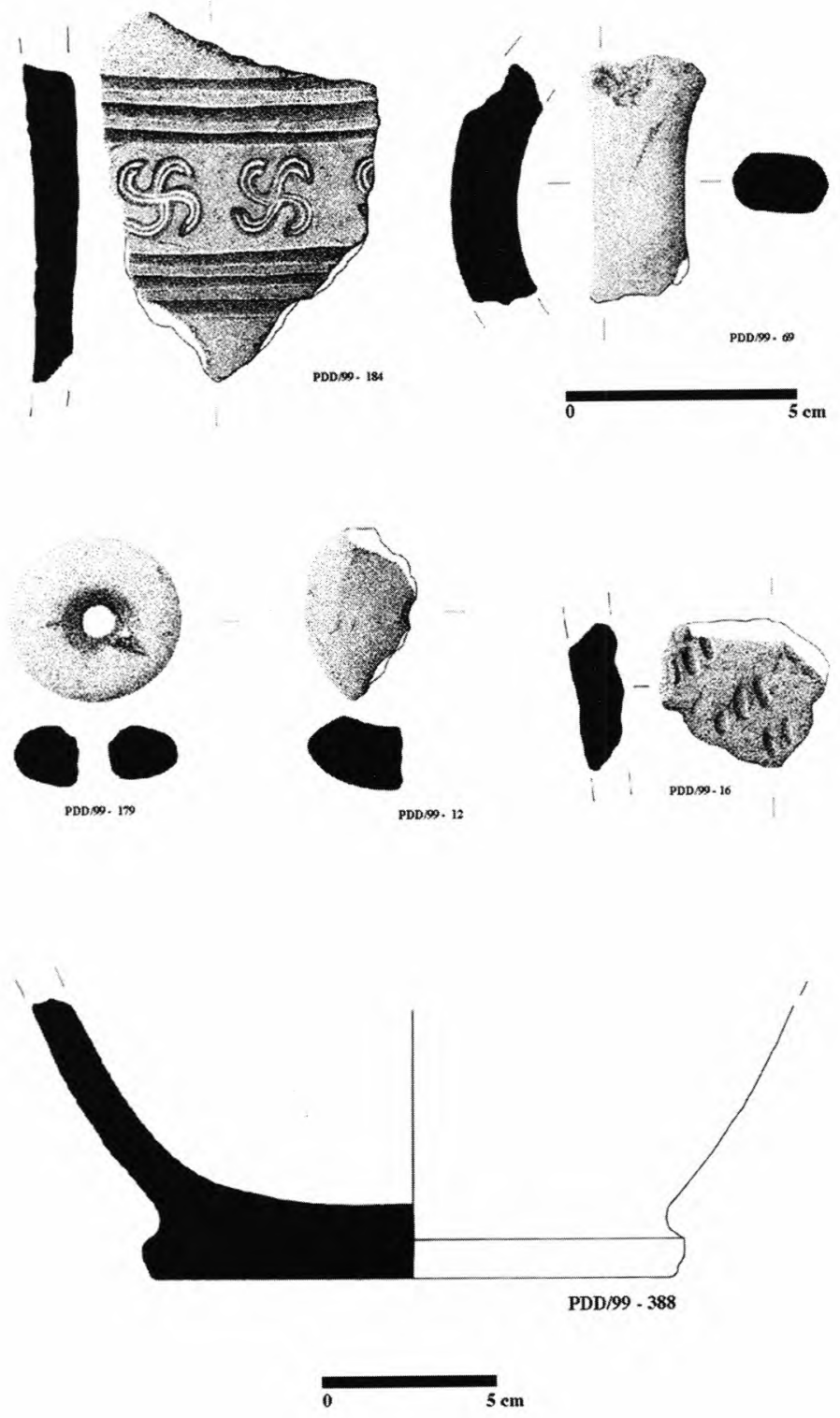
EST. XI
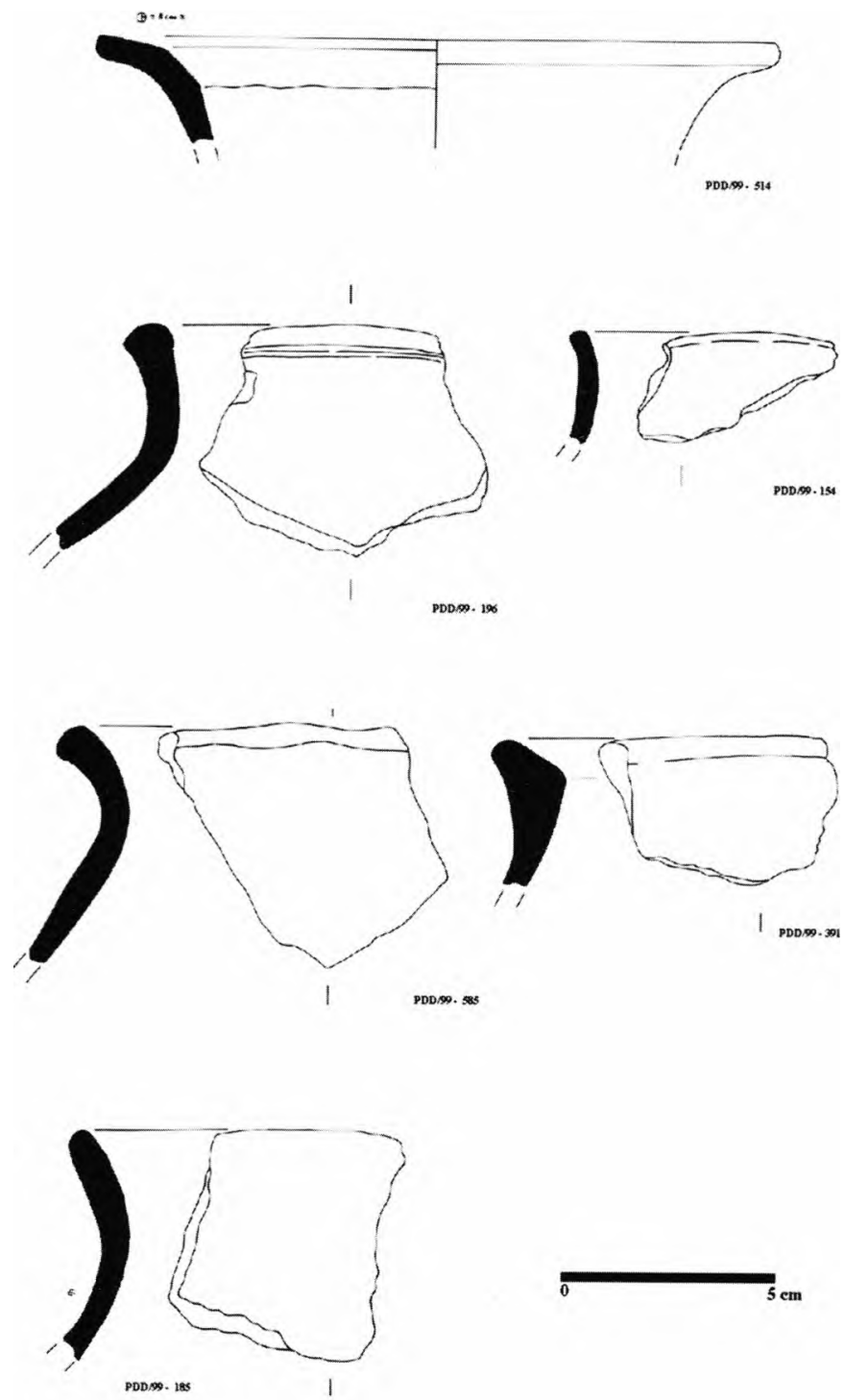
Est. XII
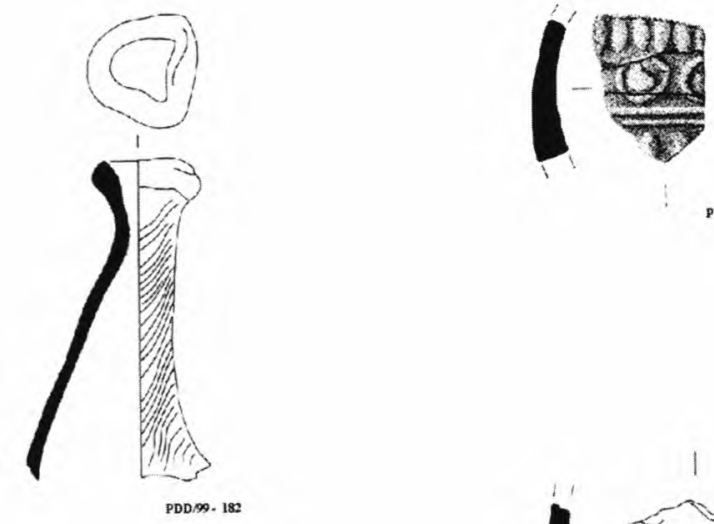

PDD 99.186
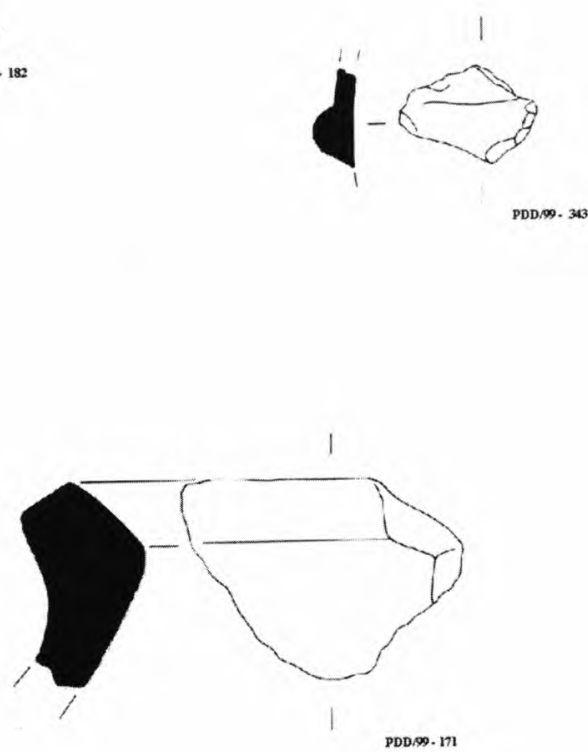

0 $5 \mathrm{~cm}$ 
EST. XIII
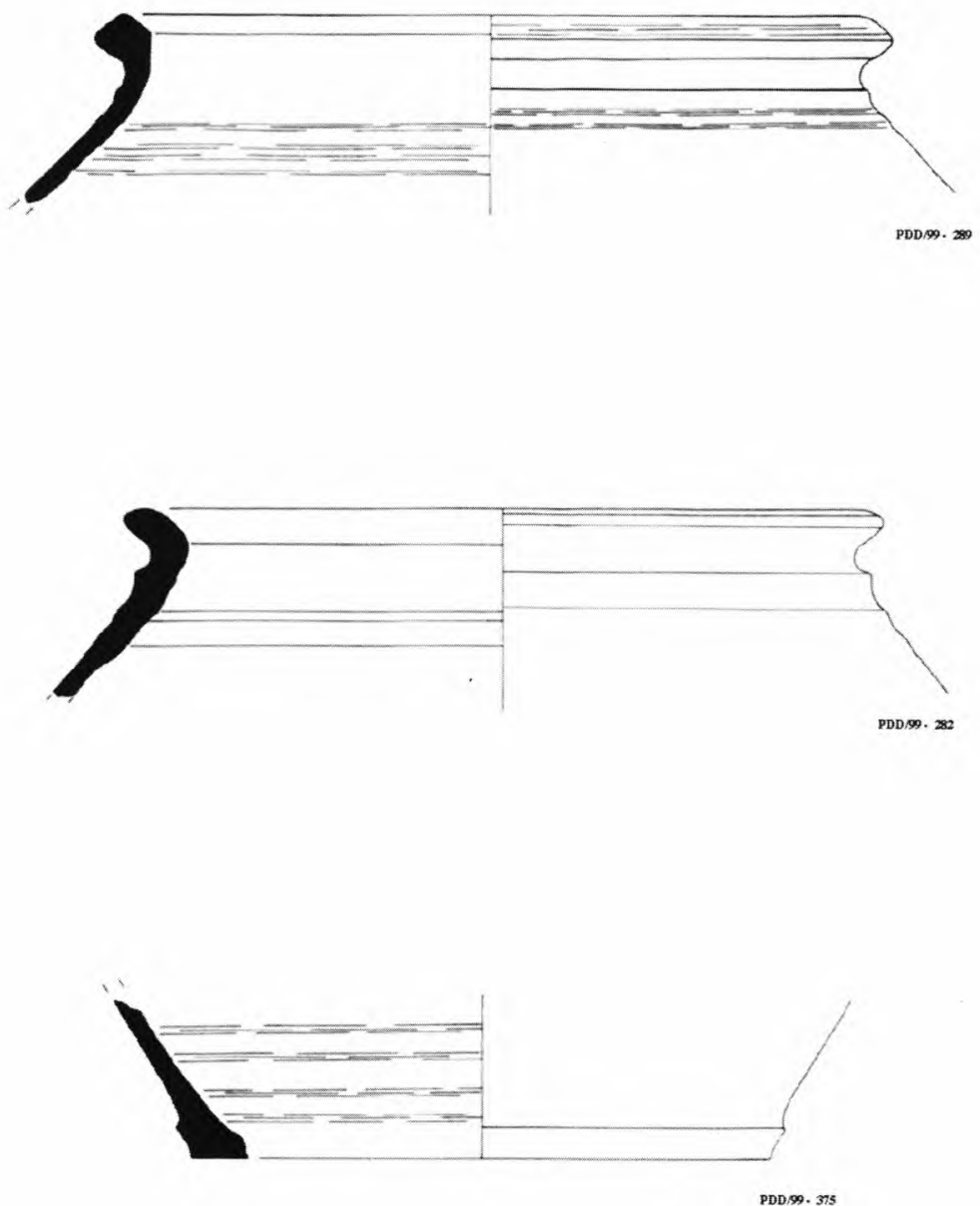

$5 \mathrm{~cm}$ 


\section{LEGENDA}

Acompanhamento arqueológico na R. Escura

R. do Gonçalinho e R. da Prebenda

Escala 1:2000

+ Limite da Zona Histórica

Piso de cabana proto-histórico

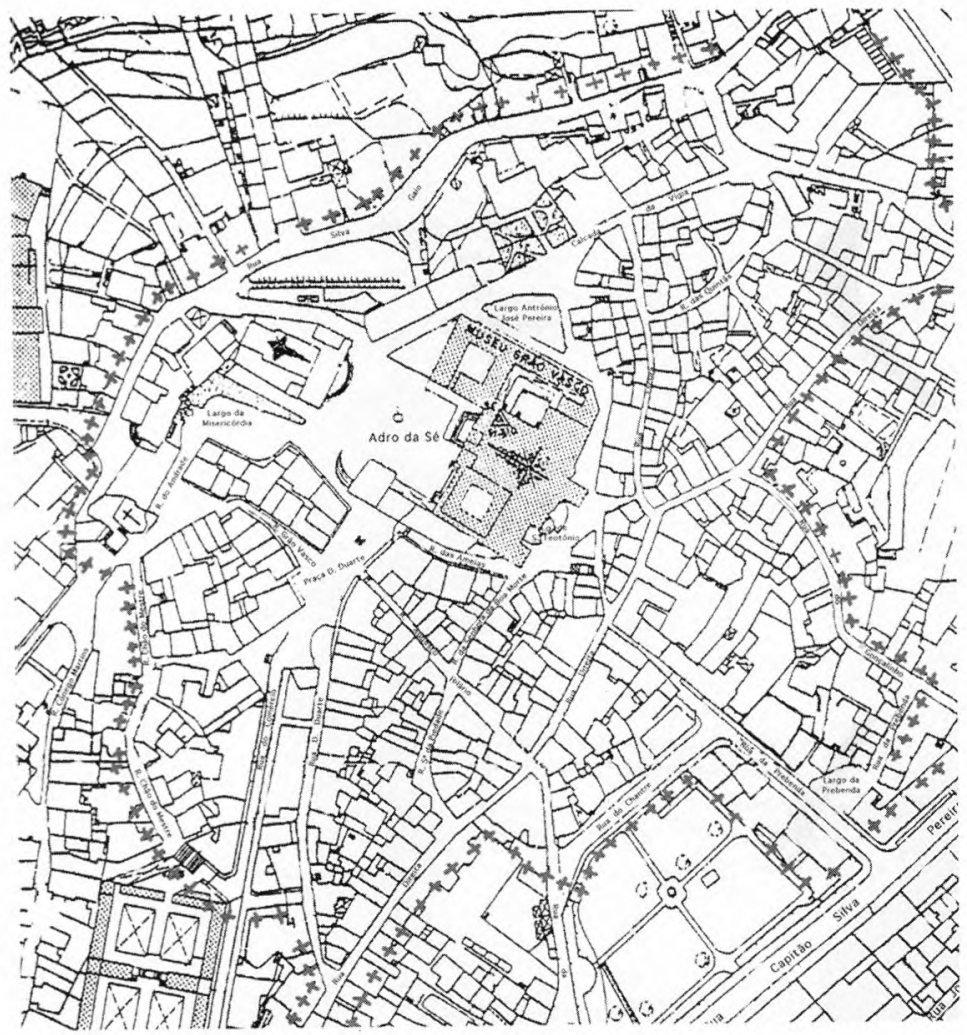


EsT. XV

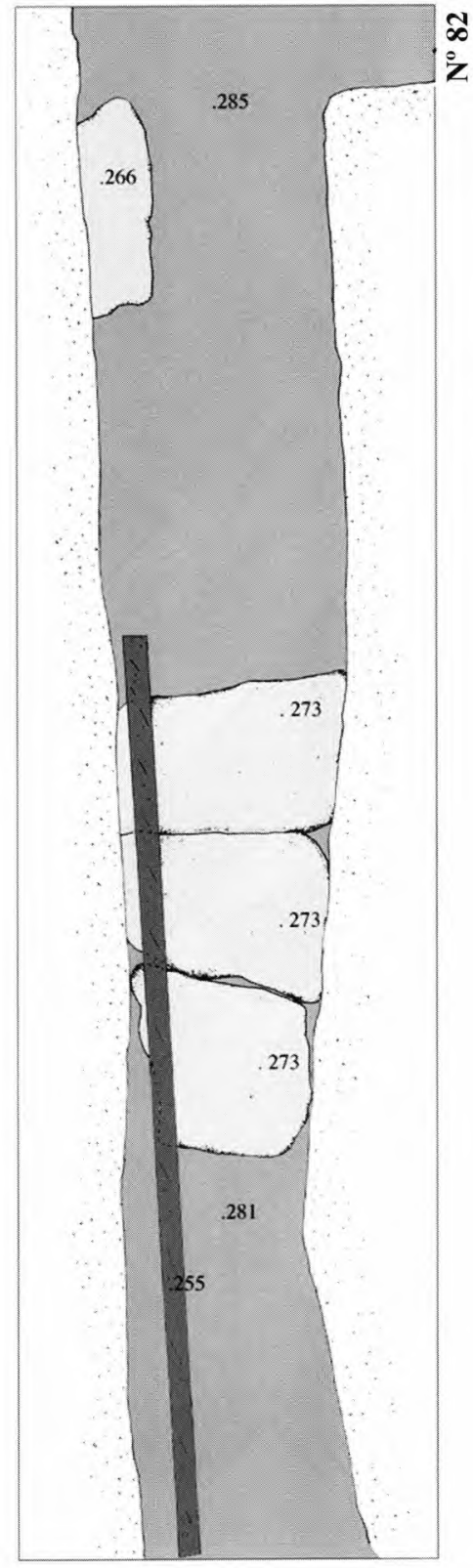

RUA DO GONCALINHO, N. ${ }^{\circ} 82$

lajes de pedra

Dano em ferro

- vala

0

$2 m$ 


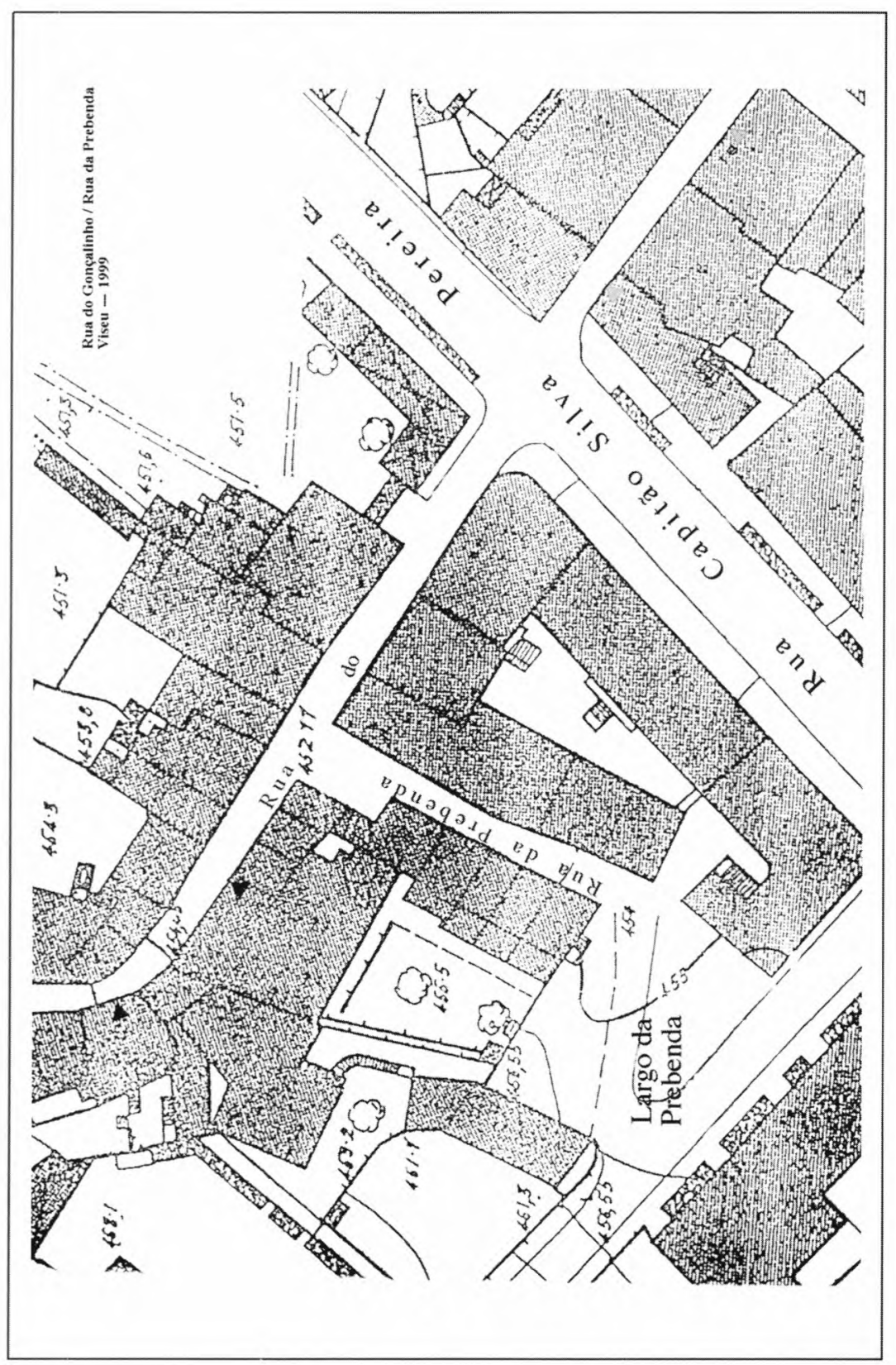


EsT. XVII

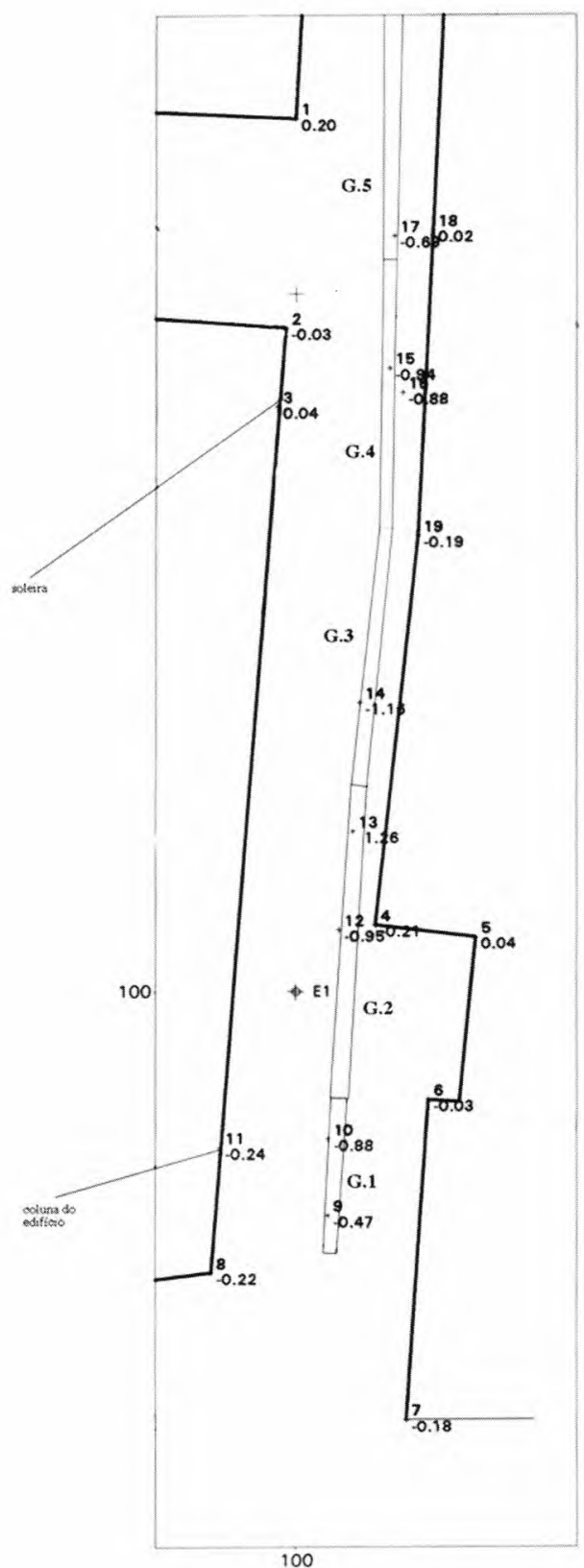

RUA DO GONÇALINHO - VISEU

Planimetria 
EsT. XVIII

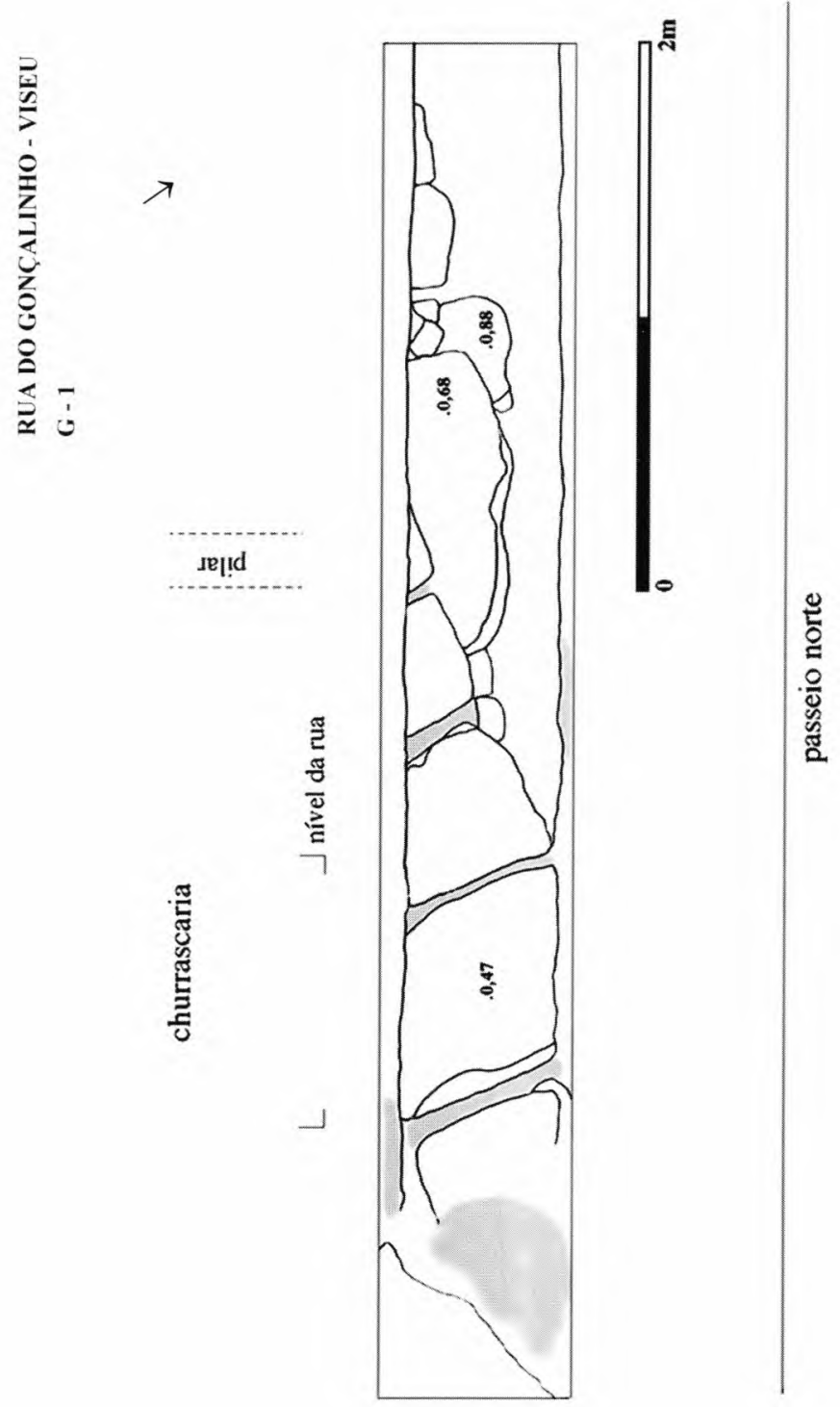


Est. XIX
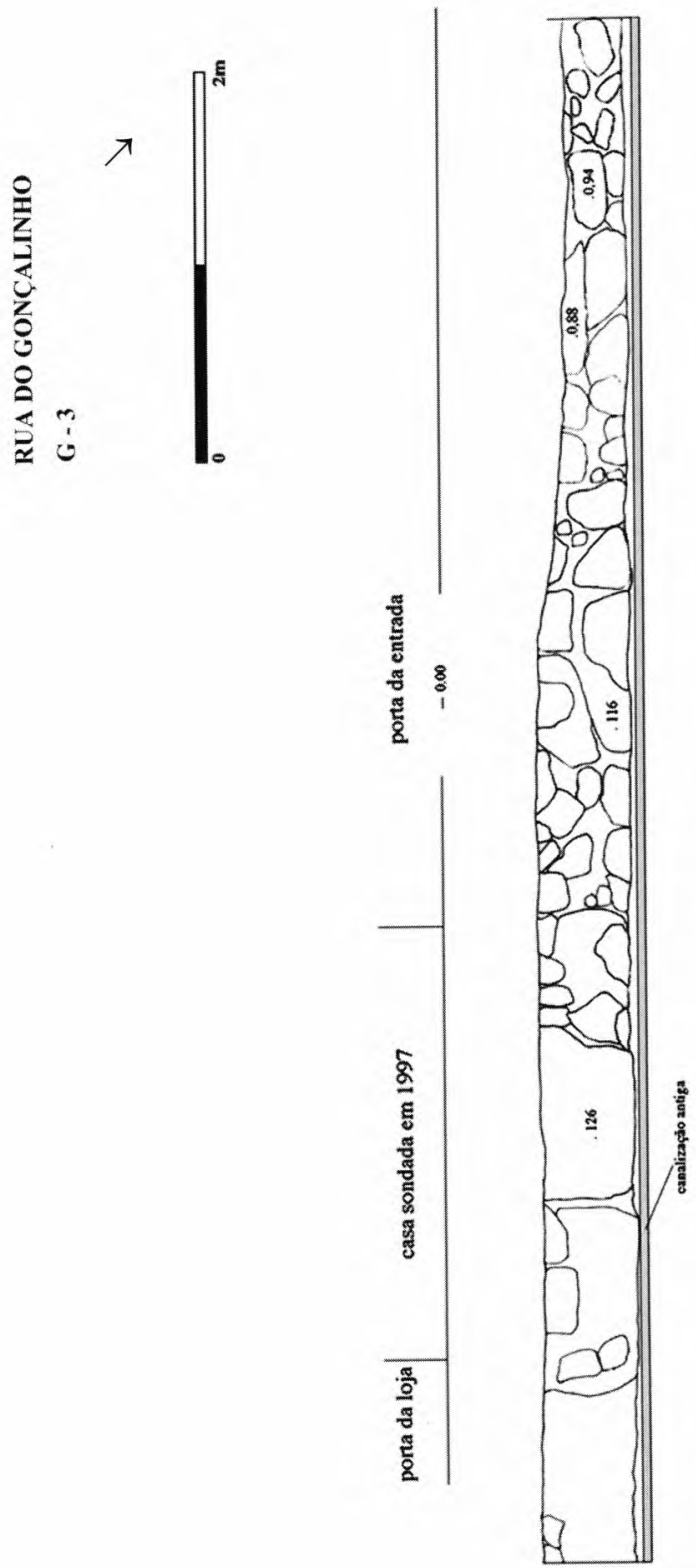
EsT. XX
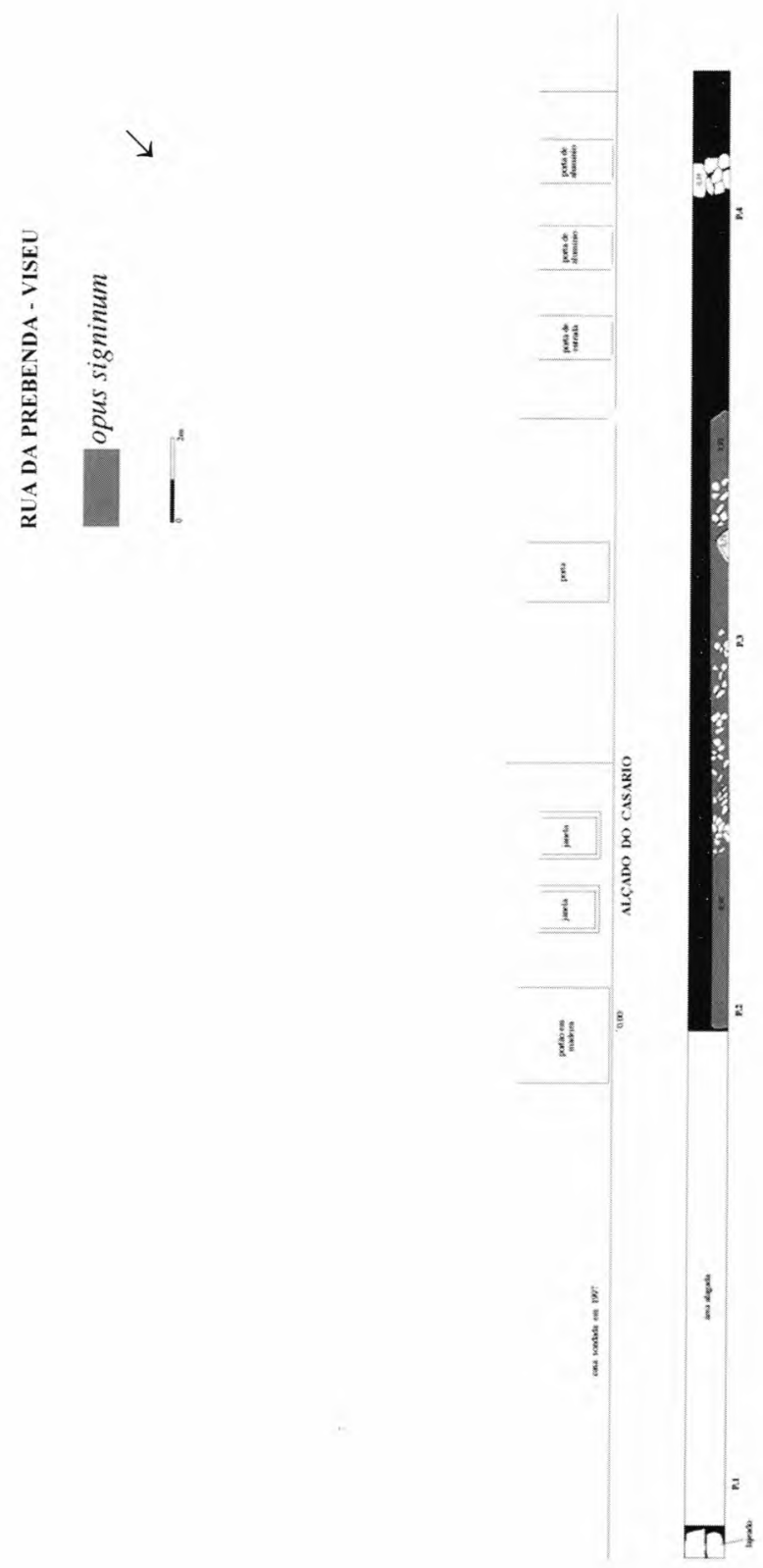